\title{
Studies of Thioamide Positional Effects on Serine Protease Activity Enable Two-Site Stabilization of Cancer Imaging Peptides
}

\author{
Taylor M. Barrett, ${ }^{1}$ Xing S. Chen, ${ }^{1}$ Chunxiao Liu, ${ }^{1,2}$ Sam Giannakoulias, ${ }^{1}$ Hoang Anh T. Phan, ${ }^{1}$ \\ Jieliang Wang, ${ }^{1}$ E. Keith Keenan, ${ }^{1}$ Richard J. Karpowicz Jr., ${ }^{1}$ and E. James Petersson ${ }^{1, *}$ \\ ${ }^{1}$ Department of Chemistry, University of Pennsylvania, 231 South 34th Street, Philadelphia, PA \\ 19104 \\ ${ }^{2}$ Department of Applied Chemistry, China Agricultural University, Yuanmingyuan West Road 2, \\ Beijing 100193, China
}

*Email: ejpetersson@sas.upenn.edu

Table of Contents

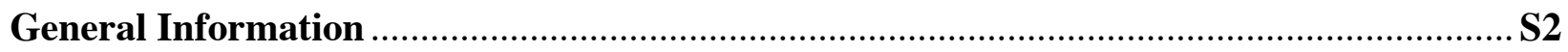

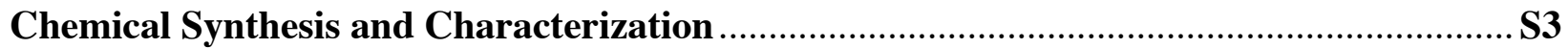

Peptide Synthesis, Purification, and Characterization ................................................. 66

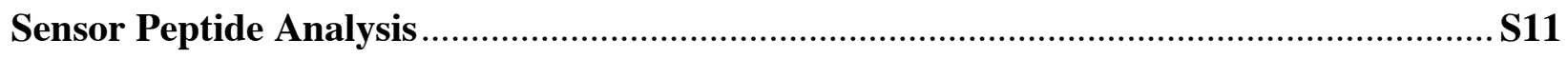

Kinetic Analysis of P1 Thioamide Peptides ...............................................................S17

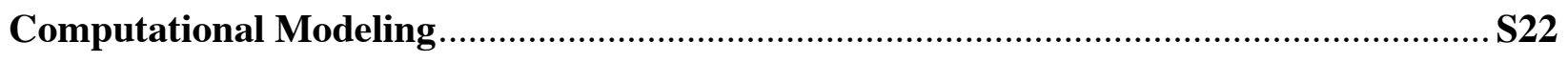

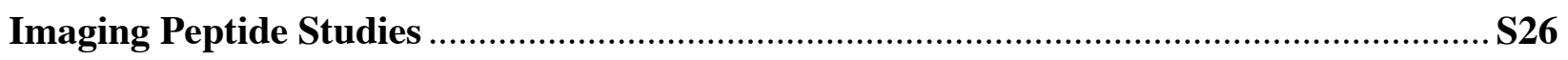

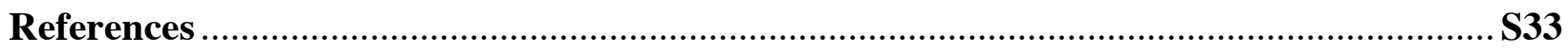


General Information. Fmoc- $\beta$-(7-methoxycoumarin-4-yl)-Ala-OH was purchased from Bachem (Torrance, CA, USA). All other Fmoc protected amino acids and 2-(1H-benzotriazol-1-yl)1,1,3,3-tetramethyluronium hexafluorophosphate (HBTU) were purchased from Novabiochem (currently EMD Millipore; Billerica, MA, USA). Piperidine was purchased from American Bioanalytical (Natick, MA, USA). 7-Azabenzotriazol-1-yloxy)tripyrrolidino-phosphonium hexafluorophosphate (PyAOP) was purchased from ChemImpex (Wood Dale, IL, USA). Sigmacote ${ }^{\circledR}, N, N$-diisopropylethylamine (DIPEA), N-benzoyl-L-arginine 4-nitroanilide, trypsin (lyophilized powder; from porcine pancreas; Type II-S; 1,000 - 2,000 units/mg dry solid), chymotrypsin (lyophilized powder; from bovine pancreas; Type II; greater than or equal to 40 units/mg dry solid) and mouse serum (M5905) were ordered from Sigma Aldrich. Kallikrein (in Tris $\mathrm{HCl}$ buffer; from human plasma; 15 units/mg protein) was ordered from Millipore Sigma. PathHunter ${ }^{\circledR}$ eXpress NPY1R CHO-K1 $\beta$-Arrestin GPCR Assay kits were purchased from DiscoverX (Fremont, CA, USA). All other reagents were purchased from Fisher Scientific (Pittsburgh, PA, USA) unless specified otherwise. Milli-Q filtered (18 M 2 ) water was used for all solutions (EMD Millipore). Time-course UV-Vis absorbance and fluorescence data were obtained with a Tecan Infinite ${ }^{\circledR}$ M1000 PRO plate reader (San Jose, CA, USA). Peptides were purified with a Varian ProStar High-Performance Liquid Chromatography (HPLC) with a diode array detector (currently Agilent Technologies), an Agilent 1260 Infinity II Preparative HPLC system, a Biotage Isolera one (Biotage, LLC, Charlotte NC) and analyzed with an Agilent 1100 or Agilent 1260 Infinity II Series Analytical HPLC system. Peptide mass spectrometry was collected with a Bruker Ultraflex III MALDI-MS mass spectrometer (Billerica, MA, USA). Nuclear magnetic resonance (NMR) spectra were collected with a Bruker DMX $500 \mathrm{MHz}$ instrument (Billerica, MA). High resolution electrospray ionization mass spectra (ESI-HRMS) were obtained 
on a Waters LCT Premier XE liquid chromatograph/mass spectrometer (Milford, MA). Cellular images were obtained using a VT-iSIM confocal microscope (VisiTech International Ltd., Sunderland, U.K.). Fluorescence lifetime measurements were made by time correlated single photon counting (TCSPC) using a Photon Technologies International (PTI) QuantaMaster40 fluorometer (currently Horiba Scientific, Edison, NJ, USA).

\section{Chemical Synthesis and Characterization.}

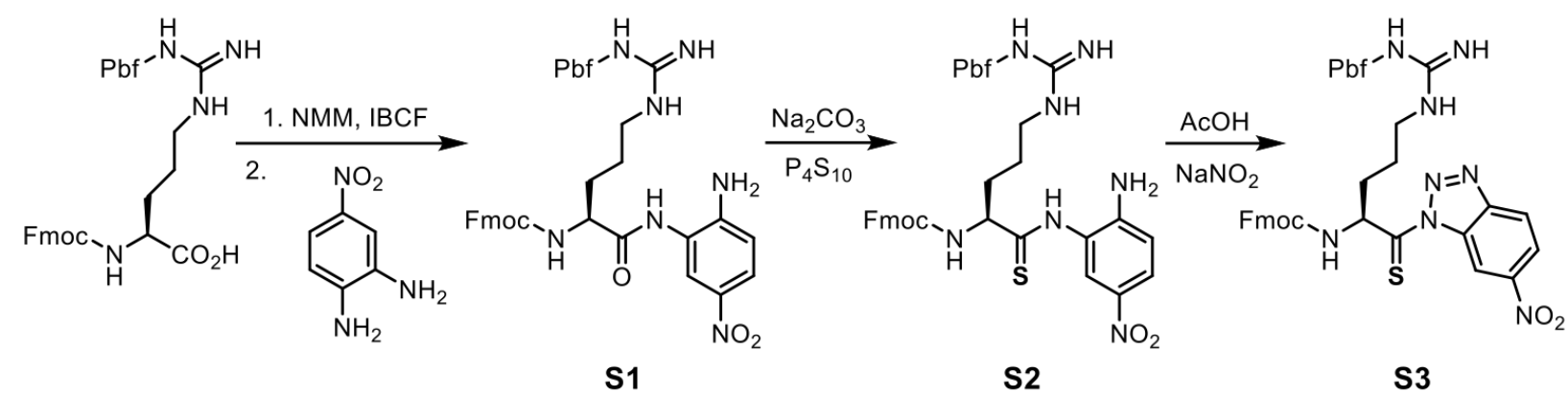

Scheme S1. Synthesis of Thioarginine Precursor.

Synthesis of $\mathbf{N}_{\alpha}$-Fmoc- $\mathbf{N}_{\omega}$-Pbf-L-arginine-2-amino-5-nitroanilide (S1). Under argon atmosphere, Fmoc-Arg(Pbf)-OH (6.48 g, $10 \mathrm{mmol}, 1$ equiv) was dissolved in $50 \mathrm{~mL}$ of dry tetrahydrofuran (THF) and equilibrated to $-10{ }^{\circ} \mathrm{C}$ in a salt ice bath $(\mathrm{NaCl} / \mathrm{ice}=1: 3)$. Under magnetic stirring, $N$-methylmorpholine (NMM, $2.20 \mathrm{~mL}, 20 \mathrm{mmol}, 2$ equiv) and isobutylchloroformate (IBCF, $1.97 \mathrm{~mL}, 10 \mathrm{mmol}, 1$ equiv) were added to the solution dropwise by a pipette. The reaction was allowed to proceed for $30 \mathrm{~min}$ at $-10^{\circ} \mathrm{C}$ with stirring. 4-nitro-1,2pheylenediamine ( $1.53 \mathrm{~g}, 10 \mathrm{mmol}, 1$ equiv) was added and the reaction was stirred at $-10^{\circ} \mathrm{C}$ until the ice melted, then at room temperature overnight. After removal of solvent by rotary evaporation, the residue was dissolved in $50 \mathrm{~mL}$ of ethyl acetate and extracted with $50 \mathrm{~mL}$ each of $1 \mathrm{M} \mathrm{Na}_{2} \mathrm{HPO}_{4}$, Brine, and 5\% $\mathrm{NaHCO}_{3}$. The organic layer was dried over magnesium sulfate and 
solvent was taken off by rotary evaporation and high vacuum. An orange solid was obtained as the final product ( $6.791 \mathrm{~g}, 8.67 \mathrm{mmol}, 87 \%$ yield) in $75 \%$ purity (determined by HPLC). $\mathrm{R}_{\mathrm{f}}=0.51$ in 9:1 ethyl acetate/hexanes. ${ }^{1} \mathrm{H}$ NMR (500 MHz, DMSO- $\left.d_{6}\right) \delta 9.34(\mathrm{~s}, 1 \mathrm{H}), 8.16(\mathrm{~d}, J=2.4 \mathrm{~Hz}$, 1H), $7.87-7.80(\mathrm{~m}, 3 \mathrm{H}), 7.69$ (q, $J=6.9 \mathrm{~Hz}, 3 \mathrm{H}), 7.37$ (t, $J=7.4 \mathrm{~Hz}, 2 \mathrm{H}), 7.29$ (t, $J=7.4 \mathrm{~Hz}$, 2H), $6.74(\mathrm{~d}, J=9.1 \mathrm{~Hz}, 1 \mathrm{H}), 4.28(\mathrm{~d}, J=7.0 \mathrm{~Hz}, 2 \mathrm{H}), 4.24-4.17(\mathrm{~m}, 2 \mathrm{H}), 4.13(\mathrm{dd}, J=14.3,6.9$ Hz, 2H), $3.09-3.01(\mathrm{~m}, 2 \mathrm{H}), 2.46$ (p, $J=1.8 \mathrm{~Hz}, 31 \mathrm{H}), 2.39$ (s, 3H), $1.95(\mathrm{~s}, 3 \mathrm{H}), 1.35(\mathrm{~s}, 6 \mathrm{H})$. ${ }^{13} \mathrm{C}$ NMR (101 MHz, $\left.\mathrm{CD}_{3} \mathrm{CN}\right) \delta 172.42,158.89,157.30,157.04,150.51,144.58,144.50,141.69$, $138.61,137.76,133.99,132.82,128.29,127.68,125.78,125.58,124.60,124.26,121.28,120.55$ $118.16,117.88,117.68,114.63,87.09,78.73,67.13,55.80,47.60,43.08,40.55,30.48,29.05$, $28.23,26.15,19.16,17.91,12.22,1.52,1.46,1.37,1.31,1.25,1.16,1.11,1.05,1.01,0.90,0.84$ 0.81, 0.69, 0.63, 0.60, 0.49, 0.39, 0.28. ESI $^{+}$-HRMS $[\mathrm{M}+\mathrm{H}]^{+}$Calculated: $784.313 \mathrm{~m} / \mathrm{z}$, Observed: $784.314 \mathrm{~m} / \mathrm{z}$

Synthesis of $N_{\alpha}$-Fmoc- $N_{\omega}$-Pbf-L-thioarginine-2-amino-5-nitroanilide (S2) Anhydrous $\mathrm{Na}_{2} \mathrm{CO}_{3}$ (0.676 g, $6.38 \mathrm{mmol}, 1$ equiv) and $\mathrm{P}_{4} \mathrm{~S}_{10}(2.84 \mathrm{~g}, 6.38 \mathrm{mmol}, 1$ equiv) were dissolved in $50 \mathrm{~mL}$ of dry THF and stirred at room temperature under argon for $30 \mathrm{~min}$ until the mixture became a clear pale yellow solution. The solution was then cooled to $0{ }^{\circ} \mathrm{C}$ over an ice bath. Compound S1 (5.00 g, $6.38 \mathrm{mmol}, 1$ equiv) was added to the solution and allowed to react under argon atmosphere overnight at $0{ }^{\circ} \mathrm{C}$, warming to room temperature. Upon completion, the solvent was removed by rotary evaporation. The crude reaction mixed was filtered through Celite to remove excess phosphorous pentasulfide. The filtrate was dry packed onto a $340 \mathrm{~g}$ silica SNAP column from Biotage (Charlotte, NC) and purified by normal phase chromatography using an ethyl acetate/hexanes gradient (50\% to $100 \%$ ethyl acetate over 12 column volumes) to yield an orange foam $\left(1.518 \mathrm{~g}, 1.899 \mathrm{mmol}, 30 \%\right.$ yield) in $100 \%$ purity (determined by HPLC). $\mathrm{R}_{\mathrm{f}}=0.24$ in 9:1 
ethyl acetate:hexanes. ${ }^{1} \mathrm{H}$ NMR (500 MHz, DMSO- $\left.d_{6}\right) \delta 11.27(\mathrm{~s}, 2 \mathrm{H}), 8.46(\mathrm{~d}, J=2.4 \mathrm{~Hz}, 1 \mathrm{H})$, $7.93(\mathrm{dd}, J=9.1,2.6 \mathrm{~Hz}, 3 \mathrm{H}), 7.86(\mathrm{t}, J=9.1 \mathrm{~Hz}, 9 \mathrm{H}), 7.78(\mathrm{dd}, J=8.7,2.5 \mathrm{~Hz}, 1 \mathrm{H}), 7.70(\mathrm{dd}, J$ $=15.9,7.5 \mathrm{~Hz}, 5 \mathrm{H}), 7.38(\mathrm{t}, J=7.4 \mathrm{~Hz}, 5 \mathrm{H}), 7.29(\mathrm{t}, J=7.4 \mathrm{~Hz}, 5 \mathrm{H}), 6.77(\mathrm{~d}, J=9.1 \mathrm{~Hz}, 3 \mathrm{H})$, $6.51(\mathrm{~d}, J=8.7 \mathrm{~Hz}, 2 \mathrm{H}), 6.32(\mathrm{~s}, 4 \mathrm{H}), 4.40(\mathrm{q}, J=6.5 \mathrm{~Hz}, 2 \mathrm{H}), 4.34-4.26(\mathrm{~m}, 3 \mathrm{H}), 4.25-4.17$ $(\mathrm{m}, 5 \mathrm{H}), 3.99(\mathrm{dd}, J=8.6,6.6 \mathrm{~Hz}, 3 \mathrm{H}), 3.72(\mathrm{qq}, J=7.1,4.0,3.6 \mathrm{~Hz}, 2 \mathrm{H}), 3.51-3.45(\mathrm{~m}, 1 \mathrm{H})$, $3.14(\mathrm{~s}, 2 \mathrm{H}), 3.08(\mathrm{q}, J=6.5 \mathrm{~Hz}, 5 \mathrm{H}), 2.91(\mathrm{~s}, 5 \mathrm{H}), 2.41(\mathrm{~s}, 7 \mathrm{H}), 1.97(\mathrm{~s}, 7 \mathrm{H}), 1.95(\mathrm{~s}, 2 \mathrm{H}), 1.36$ $(\mathrm{s}, 15 \mathrm{H}), 1.14(\mathrm{t}, J=7.1 \mathrm{~Hz}, 2 \mathrm{H}), 1.02(\mathrm{~d}, J=6.7 \mathrm{~Hz}, 6 \mathrm{H}), 0.82(\mathrm{~d}, J=6.7 \mathrm{~Hz}, 1 \mathrm{H}) .{ }^{13} \mathrm{C} \mathrm{NMR}(126$ $\left.\mathrm{MHz}, \mathrm{CDCl}_{3}\right) \delta 206.48,171.40,159.44,157.00,156.46,148.88,143.77,143.74,143.69,141.45$, $141.39,141.34,138.71,138.00,132.59,128.02,127.98,127.94,127.36,127.30,127.22,125.55$, $125.33,125.28,125.19,125.13,122.58,120.23,120.20,118.09,115.10,86.91,86.82,82.58$, $77.42,67.61,60.81,60.63,53.64,47.28,47.24,47.14,43.26,40.62,33.08,32.14,31.80,29.92$, $29.87,29.58,28.75,28.49,28.43,25.89,22.91,22.76,21.29,20.34,19.99,19.94,19.55,18.21$, 14.41, 14.35, 12.73, 12.67, 12.50. ESI ${ }^{+}-\mathrm{HRMS}[\mathrm{M}+\mathrm{H}]^{+}$Calculated: $800.290 \mathrm{~m} / \mathrm{z}$, Observed: $800.2917 \mathrm{~m} / \mathrm{z}$.

Synthesis of $\boldsymbol{N}_{\boldsymbol{\alpha}}$-Fmoc- $\boldsymbol{N}_{\boldsymbol{\omega}}$-Pbf-L-thioarginine-nitrobenzotriazolide (S3) Compound S2 (1.503 g, 1.899 mmol, 1 equiv) was added to $40 \mathrm{~mL}$ of neat glacial acetic acid at $0{ }^{\circ} \mathrm{C}$ and stirred until fully dissolved. $\mathrm{NaNO}_{2}(0.164 \mathrm{~g}, 2.374 \mathrm{mmol}, 1.25$ equiv $)$ was added in small portions with stirring over $5 \mathrm{~min}$. The reaction was allowed to stir for $30 \mathrm{~min}$ at $0{ }^{\circ} \mathrm{C}$, then quenched with 200 $\mathrm{mL}$ of ice water, resulting in an orange precipitate. The precipitate was collected by filtration, rinsed with cold water, and dried overnight by lyophilization. An orange solid was obtained as the final product (1.104 g, $1.363 \mathrm{mmol}, 72 \%$ yield) in 80\% purity (determined by HPLC). ${ }^{1} \mathrm{H}$ NMR (500 MHz, Chloroform- $d$ ) $\delta 9.53(\mathrm{~s}, 1 \mathrm{H}), 8.78(\mathrm{~d}, J=8.2 \mathrm{~Hz}, 1 \mathrm{H}), 8.48-8.32(\mathrm{~m}, 1 \mathrm{H}), 8.30$ (s, 1H), $8.24-8.15(\mathrm{~m}, 1 \mathrm{H}), 7.68(\mathrm{~d}, J=7.6 \mathrm{~Hz}, 2 \mathrm{H}), 7.55(\mathrm{t}, J=7.0 \mathrm{~Hz}, 3 \mathrm{H}), 4.41(\mathrm{~d}, J=7.1 \mathrm{~Hz}$, 
2H), $4.29(\mathrm{~d}, J=8.5 \mathrm{~Hz}, 2 \mathrm{H}), 4.12(\mathrm{td}, J=7.2,4.1 \mathrm{~Hz}, 2 \mathrm{H}), 2.88(\mathrm{~s}, 3 \mathrm{H}), 2.51(\mathrm{~d}, J=12.2 \mathrm{~Hz}$, 4H), $2.44(\mathrm{~d}, J=12.0 \mathrm{~Hz}, 5 \mathrm{H}), 2.04(\mathrm{~d}, J=12.4 \mathrm{~Hz}, 7 \mathrm{H}), 1.42(\mathrm{~s}, 10 \mathrm{H}) .{ }^{13} \mathrm{C}$ NMR $(101 \mathrm{MHz}$, DMSO) $\delta ~ 202.51,176.16,158.89,158.74,157.97,157.93,156.53,156.33,154.43,147.42$, $145.16,144.39,144.22,144.01,143.90,143.82,141.26,141.20,141.12,138.93,138.44,137.79$, 137.66, 134.61, 134.51, 133.12, 132.61, 132.57, 131.98, 131.94, 131.88, 131.84, 128.08, 127.53, $125.65,125.25,125.22,124.78,124.73,124.69,121.46,120.55,120.51,117.25,117.04,116.81$, $116.76,116.71,116.67,87.21,87.17,86.69,86.64,66.21,55.34,47.18,47.13,42.93,42.72,28.69$, $28.65,19.47,19.43,19.38,18.34,18.12,18.05,12.73,12.68,12.66 . \mathrm{ESI}^{+}-\mathrm{HRMS}[\mathrm{M}+\mathrm{H}]^{+}$ Calculated: $811.270 \mathrm{~m} / \mathrm{z}$, Observed: $811.270 \mathrm{~m} / \mathrm{z}$.

Synthesis of Other Thioaminoacid Precursors. $N_{\alpha}$-Fmoc- $N_{e}$-Boc-L-thiolysine-nitrobenzo triazolide, $N_{\alpha}$-Fmoc-L-thioleucine-nitrobenzotriazolide, $N_{\alpha}$-Fmoc-L-thiophenylalanine-nitrobenzo triazolide, and $N_{\alpha}$-Fmoc-L-thioalanine-nitrobenzotriazolide were synthesized as previously reported by our laboratory. ${ }^{1-2}$

\section{Peptide Synthesis, Purification, and Characterization.}

Peptide Synthesis. Each peptide was manually synthesized on a $25 \mu \mathrm{mol}$ scale on 2-chlorotrityl resin using our established protocols. ${ }^{3}$ Prior to use, the glass peptide reaction vessel (RV) was coated with Sigmacote ${ }^{\circledR}$ and dried under vacuum. For a typical synthesis, 2-chlorotrityl resin was added to a dry RV and swelled in $5 \mathrm{~mL}$ dimethylformamide (DMF) for 30 min with magnetic stirring. Between each reaction, the resin was washed extensively with adequate DMF. For the first amino acid coupling, 5 equiv of amino acid was dissolved in $2 \mathrm{~mL}$ of DMF and added to the $\mathrm{RV}$, following an addition of 10 equiv of DIPEA. The reaction ran for 30 min under stirring. After 
washing, the resin was incubated with $2 \mathrm{~mL}$ of $20 \%$ piperidine solution in DMF for 20 min under stirring for deprotection. The same deprotection procedure was followed for all the subsequent standard amino acids. For a typical coupling reaction, 5 equiv of amino acid and 5 equiv of HBTU or PyAOP was dissolved in DMF, and added to the RV, with an addition of 10 equiv of DIPEA. Thioamide residues were coupled and deprotected with slightly different procedures. Thioamides were coupled through pre-activated precursors, where 2 equiv of thioamide was dissolved in 1.5 $\mathrm{mL}$ of dry dichloromethane (DCM) with 2 equiv DIPEA, and stirred for $30 \mathrm{~min}$. This procedure was repeated prior to deprotection. For the deprotection of thioamides, $2 \%$ DBU $(1,8-$ diazabicyclo(5.4.0)undec-7-ene) in DMF was added to the RV and reacted three times for two min each with extensive washing with DMF and DCM between each deprotection step.

Peptide Cleavage and Purification. Upon completion of the synthesis, the resin was dried with DCM under vacuum. Peptides were cleaved off resin by treatment with a $2 \mathrm{~mL}$ fresh cleavage cocktail of trifluoroacetic acid (TFA), water, and triisopropylsilane (TIPSH) (95:2.5:2.5 v/v) for 45 min with stirring. After treatment, the cocktail solution was expelled from the RV with nitrogen and reduced to a volume of less than $1 \mathrm{~mL}$ by rotary evaporation. This TFA solution was then treated with over $10 \mathrm{~mL}$ of cold ethyl ether in order to precipitate the peptides from the cleavage solution. This precipitate was redissolved in $2 \mathrm{~mL} 50: 50 \mathrm{CH}_{3} \mathrm{CN} / \mathrm{H}_{2} \mathrm{O}$, flash frozen with liquid nitrogen, and evaporated using lyophilization. The crude was diluted in $\mathrm{CH}_{3} \mathrm{CN} / \mathrm{H}_{2} \mathrm{O}(1: 1 \mathrm{v} / \mathrm{v})$ and then purified on a Vydac 218TP C18 prep column (Grace/Vydac; Deerfield, IL, USA) by HPLC using the following gradients (Table S1, Table S2) at a flow rate of $12 \mathrm{~mL} / \mathrm{min}$. MALDIMS was used to confirm peptide identities (Table S3). Purified peptides were dried on a lyophilizer (Labconco; Kansas City, MO, USA) or in a vacuum centrifuge (Savant/Thermo 
Scientific; Rockford, IL, USA). If needed, peptides were subjected to multiple rounds of purification until $99 \%$ purity was achieved.

Table S1. Peptide Purification Methods and Retention Time.

\begin{tabular}{|c|c|c|}
\hline Peptide & Gradient & Retention Time \\
\hline$\mu$ LLKAAA $\mu$ & 1 & $35 \mathrm{~min}$ \\
\hline$\mu \mathrm{L}^{\mathrm{S}} \mathrm{LKAAA} \mu$ & 1 & $33 \mathrm{~min}$ \\
\hline$\mu \mathrm{LL}^{\mathrm{S}} \mathrm{KAAA} \mu$ & 1 & $35 \mathrm{~min}$ \\
\hline$\mu \mathrm{LLK}^{\mathrm{S}} \mathrm{AAA} \mu$ & 1 & $35 \mathrm{~min}$ \\
\hline$\mu \mathrm{LLKA}^{\mathrm{S}} \mathrm{AA} \mu$ & 2 & $28 \mathrm{~min}$ \\
\hline$\mu \operatorname{LLKAA}^{\mathrm{S}} \mathrm{A} \mu$ & 2 & $28 \mathrm{~min}$ \\
\hline$\mu \operatorname{LLKAAA}^{\mathrm{S}} \mu$ & 2 & $28 \mathrm{~min}$ \\
\hline$\mu$ LLRAAA $\mu$ & 1 & $35 \mathrm{~min}$ \\
\hline$\mu \mathrm{L}^{\mathrm{S}} \mathrm{LRAAA} \mu$ & 3 & $18 \mathrm{~min}$ \\
\hline$\mu L L^{\mathrm{S}} \mathrm{RAAA} \mu$ & 2 & $22 \mathrm{~min}$ \\
\hline$\mu \operatorname{LLR}^{\mathrm{S}} \mathrm{AAA} \mu$ & 1 & $35 \mathrm{~min}$ \\
\hline$\mu$ LLRA $^{\mathrm{S}} \mathrm{AA} \mu$ & 3 & $21 \mathrm{~min}$ \\
\hline$\mu \operatorname{LLRAA}^{\mathrm{S}} \mathrm{A} \mu$ & 3 & $20 \mathrm{~min}$ \\
\hline$\mu \operatorname{LLRAAA}^{\mathrm{S}} \mu$ & 3 & $23 \mathrm{~min}$ \\
\hline$\mu \mathrm{KAAFAАA} \mu$ & 4 & $23 \mathrm{~min}$ \\
\hline$\mu \mathrm{K}^{\mathrm{S}} \mathrm{AAFAAA} \mu$ & 5 & $20 \mathrm{~min}$ \\
\hline$\mu \mathrm{KA}^{\mathrm{S}} \mathrm{AFAAA} \mu$ & 5 & $20 \mathrm{~min}$ \\
\hline$\mu \mathrm{KAA}^{\mathrm{S}} \mathrm{FAAA} \mu$ & 5 & $23 \mathrm{~min}$ \\
\hline$\mu \mathrm{KAAF}^{\mathrm{S}} \mathrm{AAA} \mu$ & 5 & $22 \mathrm{~min}$ \\
\hline$\mu \mathrm{KAAFA}^{\mathrm{S}} \mathrm{AA} \mu$ & 5 & $22 \mathrm{~min}$ \\
\hline$\mu \mathrm{KAAFAA}^{\mathrm{s}} \mathrm{A} \mu$ & 5 & $23 \mathrm{~min}$ \\
\hline$\mu \mathrm{KAAFAAA}^{\mathrm{S}} \mu$ & 5 & $24 \mathrm{~min}$ \\
\hline
\end{tabular}

${ }^{*} \mu$ : 7-methoxycoumarinylalanine; $A^{S}$ : thioalanine; $L^{S}$ : thioleucine; $K^{S}$ : thiolysine; $R^{S}$ : thioarginine; $F^{S}$ : thiophenylalanine 
Table S2. HPLC Gradients for Peptide Purification.

\begin{tabular}{|c|c|c|c|c|c|}
\hline No. & Time (min) & $\% B$ & No. & Time (min) & $\% B$ \\
\hline \multirow[t]{7}{*}{1} & $0: 00$ & 2 & 2 & $0: 00$ & 2 \\
\hline & $6: 00$ & 2 & & $6: 00$ & 2 \\
\hline & 8:00 & 15 & & $8: 00$ & 20 \\
\hline & $37: 00$ & 40 & & $28: 00$ & 40 \\
\hline & 40:00 & 100 & & $31: 00$ & 100 \\
\hline & $45: 00$ & 100 & & $36: 00$ & 100 \\
\hline & 50:00 & 2 & & 41:00 & 2 \\
\hline \multirow[t]{8}{*}{3} & $0: 00$ & 10 & 4 & $0: 00$ & 2 \\
\hline & $2: 00$ & 10 & & $6: 00$ & 2 \\
\hline & 5:00 & 20 & & 9:00 & 20 \\
\hline & $25: 00$ & 40 & & $24: 00$ & 40 \\
\hline & $26: 00$ & 40 & & 28:00 & 100 \\
\hline & $27: 00$ & 100 & & $33: 00$ & 100 \\
\hline & 30:00 & 100 & & $48: 00$ & 2 \\
\hline & $35: 00$ & 10 & & & \\
\hline \multirow[t]{7}{*}{5} & 0:00 & 2 & & & \\
\hline & $6: 00$ & 2 & & & \\
\hline & 8:00 & 27 & & & \\
\hline & $24: 00$ & 35 & & & \\
\hline & $26: 00$ & 100 & & & \\
\hline & $31: 00$ & 100 & & & \\
\hline & $36: 00$ & 2 & & & \\
\hline
\end{tabular}

* Solvent A: $0.1 \%$ TFA in water; Solvent B: $0.1 \%$ TFA in acetonitrile 
Table S3. Calculated and Observed Masses of Peptides.

\begin{tabular}{|c|c|c|c|c|c|c|}
\hline \multirow{2}{*}{ Peptide } & \multicolumn{2}{|c|}{$[\mathbf{M}+\mathbf{H}]^{+}(\mathbf{m} / \mathbf{z})$} & \multicolumn{2}{|c|}{$[\mathrm{M}+\mathrm{Na}]^{+}(\mathbf{m} / \mathbf{z})$} & \multicolumn{2}{|c|}{$[\mathbf{M}+\mathbf{K}]^{+}(\mathbf{m} / \mathbf{z})$} \\
\hline & Calculated & Observed & Calculated & Observed & Calculated & Observed \\
\hline$\mu$ LLKAAA $\mu$ & 1076.53 & 1075.81 & 1098.51 & 1097.79 & 1114.49 & 1113.77 \\
\hline$\mu \mathrm{L}^{\mathrm{S}} \mathrm{LKAAA} \mu$ & 1092.51 & 1092.44 & 1114.49 & 1114.42 & 1130.46 & 1130.39 \\
\hline$\mu \mathrm{LL}^{\mathrm{S}} \mathrm{KAAA} \mu$ & 1092.51 & 1092.42 & 1114.49 & 1114.40 & 1130.46 & 1130.37 \\
\hline$\mu \mathrm{LLK}^{\mathrm{S}} \mathrm{AAA} \mu$ & 1092.51 & 1092.87 & 1114.49 & 1114.85 & 1130.46 & 1130.84 \\
\hline$\mu$ LLKA $^{\mathrm{S}} \mathrm{AA} \mu$ & 1092.51 & 1092.43 & 1114.49 & 1114.41 & 1130.46 & 1130.38 \\
\hline$\mu \operatorname{LLKAA}^{\mathrm{S}} \mathrm{A} \mu$ & 1092.51 & 1092.38 & 1114.49 & 1114.36 & 1130.46 & 1130.43 \\
\hline$\mu \operatorname{LLKAAA}^{\mathrm{S}} \mu$ & 1092.51 & 1092.52 & 1114.49 & 1114.51 & 1130.46 & 1130.47 \\
\hline$\mu$ LLRAAA $\mu$ & 1104.54 & 1104.11 & 1126.52 & 1126.11 & 1142.49 & 1142.08 \\
\hline$\mu \mathrm{L}^{\mathrm{S}} \mathrm{LRAAA} \mu$ & 1120.51 & 1120.48 & 1142.50 & 1142.57 & 1158.47 & 1158.57 \\
\hline$\mu L L^{\mathrm{S}} \mathrm{RAAA} \mu$ & 1120.51 & 1120.64 & 1142.50 & 1142.61 & 1158.47 & 1158.59 \\
\hline$\mu \operatorname{LLR}^{\mathrm{S}} \mathrm{AAA} \mu$ & 1120.51 & 1120.54 & 1142.50 & 1142.53 & 1158.47 & 1158.50 \\
\hline$\mu$ LLRA $^{\mathrm{S}} \mathrm{AA} \mu$ & 1120.51 & 1120.40 & 1142.50 & 1142.58 & 1158.47 & 1158.41 \\
\hline$\mu \operatorname{LLRAA}^{\mathrm{S}} \mathrm{A} \mu$ & 1120.51 & 1120.42 & 1142.50 & 1142.47 & 1158.47 & 1158.58 \\
\hline$\mu \operatorname{LLRAAA}^{\mathrm{S}} \mu$ & 1120.51 & 1120.83 & 1142.50 & 1142.88 & 1158.47 & 1158.82 \\
\hline$\mu \mathrm{KAAFAAA} \mu$ & 1139.50 & 1139.77 & 1161.49 & 1161.80 & 1177.46 & 1177.79 \\
\hline$\mu \mathrm{K}^{\mathrm{S}} \mathrm{AAFAAA} \mu$ & 1155.48 & 1155.54 & 1177.46 & 1177.57 & 1193.44 & 1193.55 \\
\hline$\mu \mathrm{KA}^{\mathrm{S}} \mathrm{AFAAA} \mu$ & 1155.48 & 1155.68 & 1177.46 & 1177.68 & 1193.44 & 1193.67 \\
\hline$\mu \mathrm{KAA}^{\mathrm{S}} \mathrm{FAAA} \mu$ & 1155.48 & 1155.12 & 1177.46 & 1177.12 & 1193.44 & 1193.11 \\
\hline$\mu \mathrm{KAAF}^{\mathrm{S}} \mathrm{AAA} \mu$ & 1155.48 & 1155.80 & 1177.46 & 1177.88 & 1193.44 & 1193.93 \\
\hline$\mu \mathrm{KAAFA}^{\mathrm{S}} \mathrm{AA} \mu$ & 1155.48 & 1155.73 & 1177.46 & 1177.72 & 1193.44 & 1193.68 \\
\hline$\mu \mathrm{KAAFAA}^{\mathrm{S}} \mathrm{A} \mu$ & 1155.48 & 1155.71 & 1177.46 & 1177.74 & 1193.44 & 1193.73 \\
\hline$\mu \mathrm{KAAFAAA}^{\mathrm{S}} \mu$ & 1155.48 & 1155.54 & 1177.46 & 1177.45 & 1193.44 & 1193.72 \\
\hline
\end{tabular}

* $\mu$ : 7-methoxycoumarinylalanine; $A^{s}$ : thioalanine; $L^{S}$ : thioleucine; $K^{S}$ : thiolysine; $R^{s}$ : thioarginine; $F^{s}$ : thiophenylalanine 


\section{Sensor Peptide Analysis}

Steady State Protease Assays. In a typical trial, a $7.5 \mu \mathrm{M}$ solution of peptide was incubated in the presence or absence of $0.2 \mathrm{mg} / \mathrm{mL}$ chymotrypsin in $100 \mathrm{mM}$ Tris- $\mathrm{HCl}, \mathrm{pH} 7.8$ at $25^{\circ} \mathrm{C}$, or in the presence or absence of $25 \mu \mathrm{g} / \mathrm{mL}$ trypsin in $67 \mathrm{mM}$ sodium phosphate, $\mathrm{pH} 7.6$ at $25^{\circ} \mathrm{C}$, or in the presence or absence of $4.3 \mu \mathrm{g} / \mathrm{mL}$ kallikrein in $20 \mathrm{mM}$ Tris- $\mathrm{HCl}, 100 \mathrm{mM} \mathrm{NaCl}$, pH 7.5 buffer at $25{ }^{\circ} \mathrm{C}$. The fluorescence was monitored as a function of time at $390 \mathrm{~nm}$ with an excitation wavelength of $325 \mathrm{~nm}$ on the Tecan plate reader. Three independent trials were performed for each assay to ensure reproducibility. Primary data are shown in Figures S1-S4. The data from the fluorescent trials were averaged and cleavage percentages were calculated by dividing the fluorescence change of each time point by the fluorescence change of complete cleavage (measured up to $6 \mathrm{~h}$ ). Initial rates were determined by fitting a line to early timepoints (first $2 \mathrm{~min}$ ) and later timepoints (between min 10 to 20) if a biphasic curve was observed. These are reported in Table $\mathbf{S 4 a / b}$ (with standard error) and normalized rates are given in the main text.

Table S4a. Initial Rates of Peptides Cleavage by Serine Proteases.

\begin{tabular}{|c|c|c|c|}
\hline Trypsin Lys Peptides & Rate $\left(\mu \mathrm{M} \cdot \mathbf{M i n}^{-1}\right)$ & Trypsin Arg Peptides & Rate $\left(\mu \mathrm{M} \cdot \mathbf{M i n}^{-1}\right)$ \\
\hline Lys Control & $1.900 \pm 0.101$ & Arg Control & $3.320 \pm 0.902$ \\
\hline Lys P3 & $0.939 \pm 0.037$ & Arg P3 & $1.838 \pm 0.101$ \\
\hline Lys P2 & $1.787 \pm 0.019$ & Arg P2 & $3.458 \pm 0.093$ \\
\hline Lys P1 & $\begin{array}{l}0.177 \pm 0.017^{\mathrm{a}} \\
0.011 \pm 0.002^{\mathrm{b}}\end{array}$ & Arg P1 & $0.016 \pm 0.001$ \\
\hline Lys P1' & $0.990 \pm 0.073$ & $\operatorname{Arg} P 1^{\prime}$ & $3.222 \pm 0.304$ \\
\hline Lys P2' & $1.140 \pm 0.031$ & Arg P2' & $5.405 \pm 0.125$ \\
\hline Lys P3' & $1.048 \pm 0.021$ & Arg P3' & $4.953 \pm 0.166$ \\
\hline
\end{tabular}

${ }^{\mathrm{a} C l e a v a g e}$ rate during first five $\mathrm{min}$. ${ }^{\mathrm{b}} \mathrm{Cleavage}$ rate during $10-40 \mathrm{~min}$. 
Table S4b. Initial Rates of Peptides Cleavage by Serine Proteases.

\begin{tabular}{|c|c|c|c|}
\hline Chymotrypsin Peptides & Rate $\left(\mu \mathrm{M} \cdot \mathbf{M i n}^{-1}\right)$ & Kallikrein Peptides & Rate $\left(\mu \mathrm{M} \cdot \mathbf{M i n}^{-1}\right)$ \\
\hline Phe Control & $6.049 \pm 0.469$ & Arg Control & $0.634 \pm 0.021$ \\
\hline Phe P3 & $1.311 \pm 0.181$ & Arg P3 & $0.022 \pm 0.006$ \\
\hline Phe P2 & $0.010 \pm 0.001$ & $\operatorname{Arg} \mathrm{P} 2$ & $0.390 \pm 0.016$ \\
\hline Phe P1 & $0.012 \pm 0.001$ & $\operatorname{Arg} \mathrm{P} 1$ & $0.002 \pm 0.001$ \\
\hline Phe P1' & $10.050 \pm 0.440$ & Arg P1' & $0.544 \pm 0.065$ \\
\hline Phe P2' & $7.826 \pm 0.532$ & Arg P2' & $0.601 \pm 0.013$ \\
\hline Phe P3' & $9.452 \pm 0.118$ & Arg P3' & $0.690 \pm 0.019$ \\
\hline
\end{tabular}



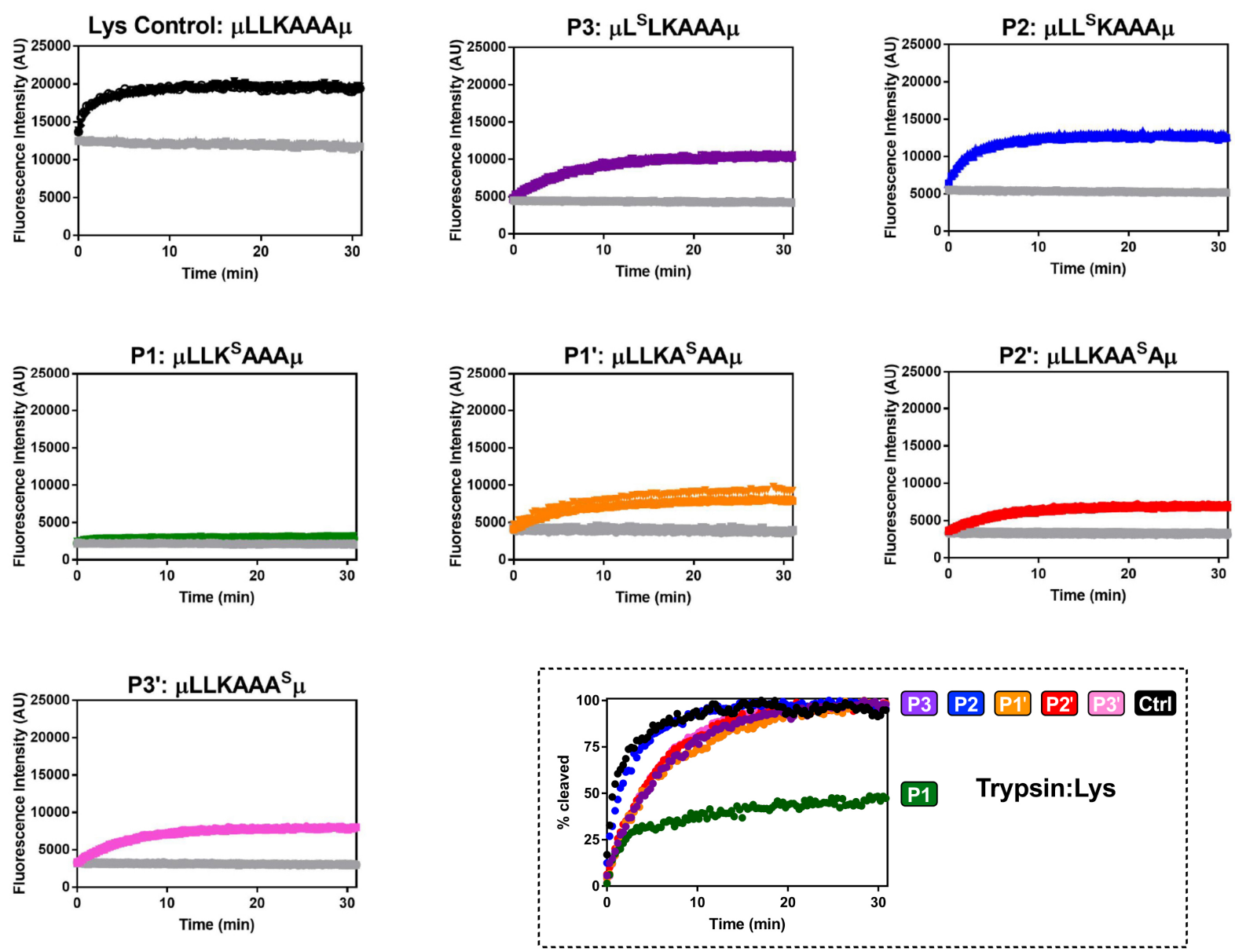

Figure S1. Trypsin Proteolysis of Lys Peptides Monitored by Fluorescence. A $7.5 \mu \mathrm{M}$ solution of peptide was incubated in the presence or absence of $25 \mu \mathrm{g} / \mathrm{mL}$ of trypsin in $67 \mathrm{mM}$ sodium phosphate buffer $(\mathrm{pH}$ 7.6) at $25^{\circ} \mathrm{C}$. Three independent trials for each peptide are shown. Black trace: All amide Lys Control peptide in the presence of protease; Colored traces: Lys thioamide peptides in the presence of protease; Grey traces: Thioamide peptides or control peptide in the absence of protease. Inset: Normalized cleavage data for control and thioamide peptides colored as indicated. 

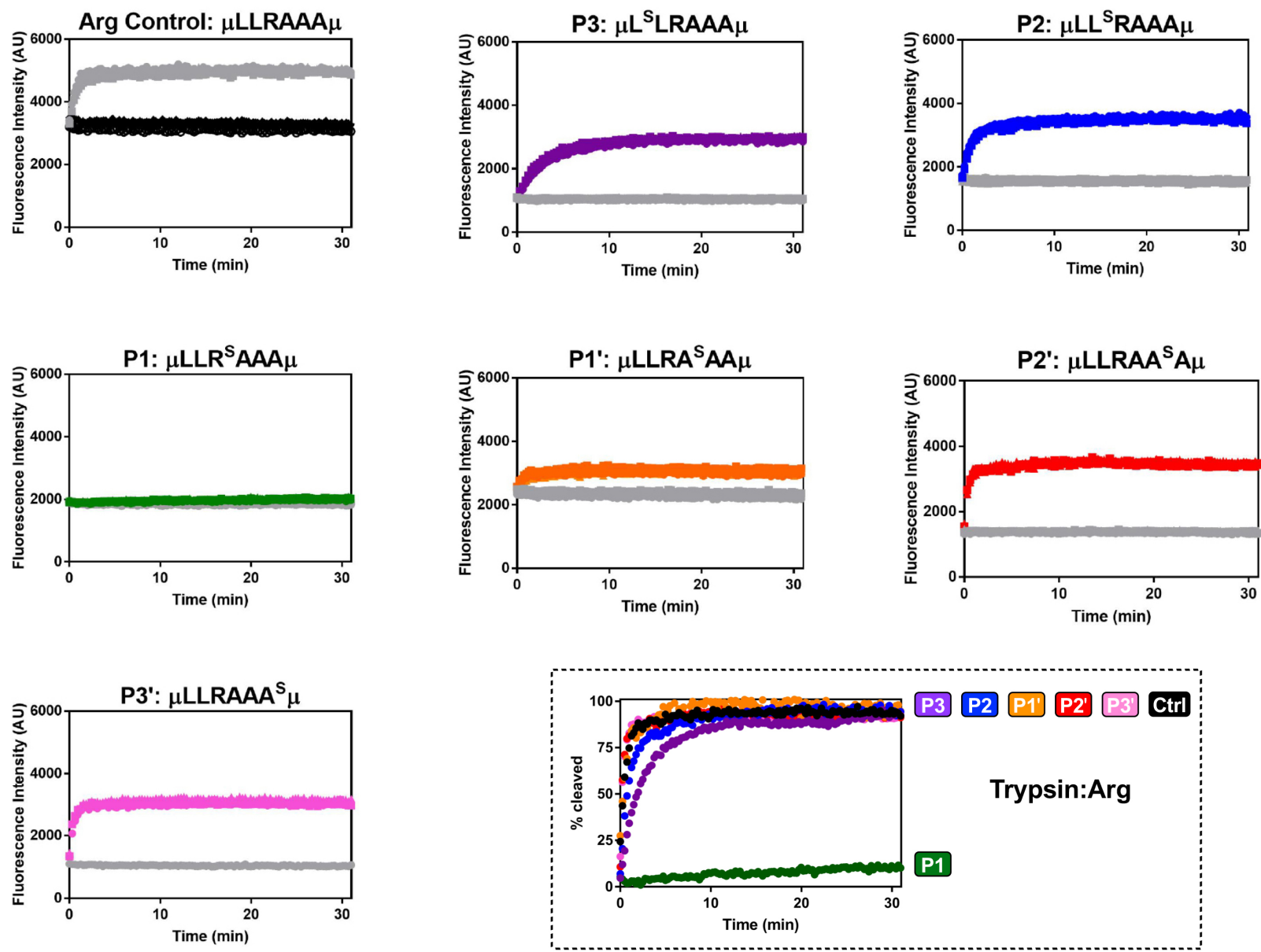

Figure S2. Trypsin Proteolysis of Arg Peptides Monitored by Fluorescence. A $7.5 \mu \mathrm{M}$ solution of peptide was incubated in the presence or absence of $25 \mu \mathrm{g} / \mathrm{mL}$ of trypsin in $67 \mathrm{mM}$ sodium phosphate buffer $(\mathrm{pH}$ 7.6) at $25^{\circ} \mathrm{C}$. Three independent trials for each peptide are shown. Black trace: All amide Arg Control peptide in the presence of protease; Colored traces: Arg thioamide peptides in the presence of protease; Grey traces: Thioamide peptides or control peptide in the absence of protease. Inset: Normalized cleavage data for control and thioamide peptides colored as indicated. 

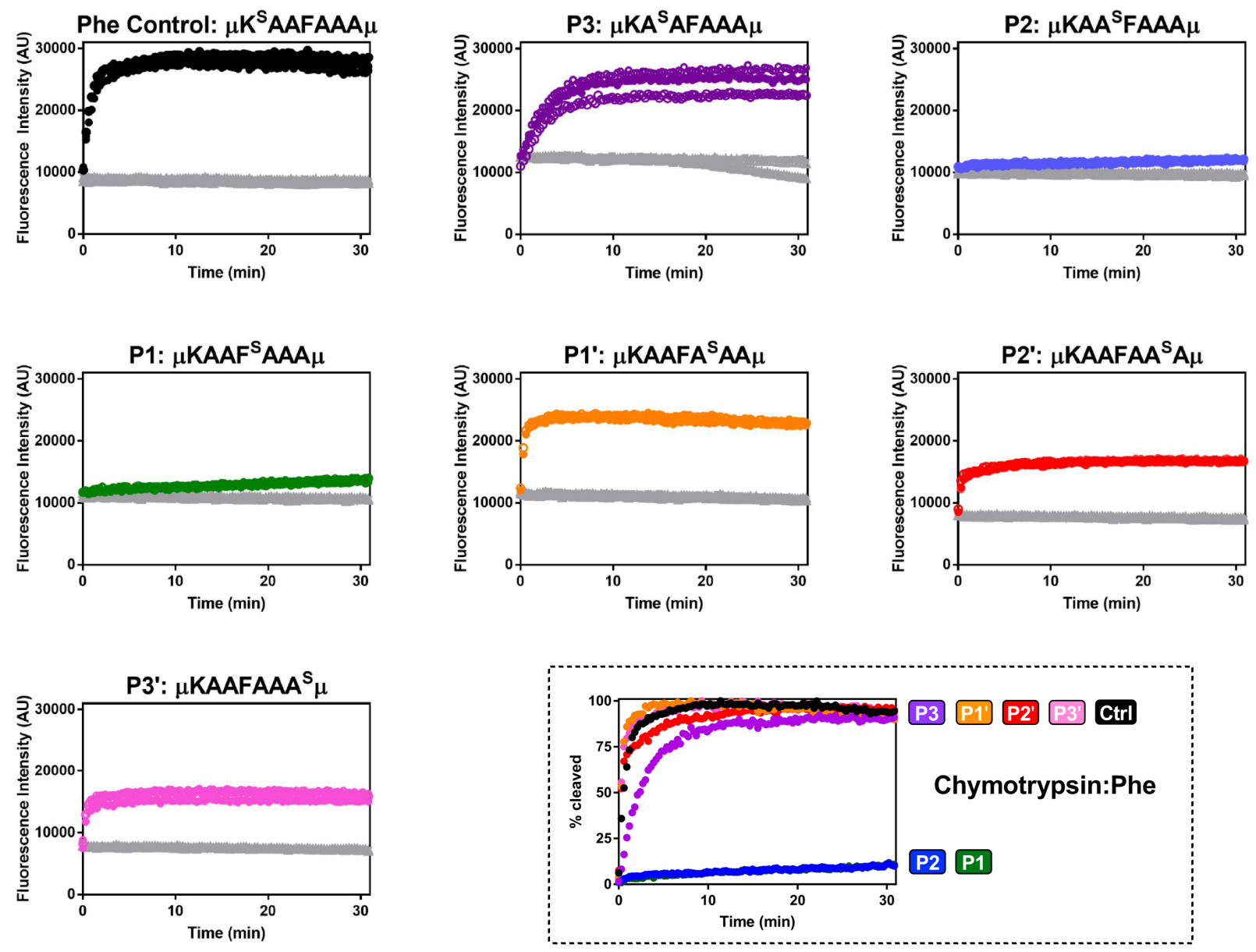

Figure S3. Chymotrypsin Proteolysis of Phe Peptides Monitored by Fluorescence. A $7.5 \mu \mathrm{M}$ solution of peptide was incubated in the presence or absence of $0.2 \mathrm{mg} / \mathrm{mL}$ chymotrypsin in $100 \mathrm{mM} \mathrm{Tris}-\mathrm{HCl}, \mathrm{pH} 7.8$ at $25^{\circ} \mathrm{C}$. Three independent trials for each peptide are shown. Black trace: P4 thioamide Phe Control peptide in the presence of protease; Colored traces: Phe thioamide peptides in the presence of protease; Grey traces: Thioamide peptides or control peptide in the absence of protease. Inset: Normalized cleavage data for control and thioamide peptides colored as indicated. 

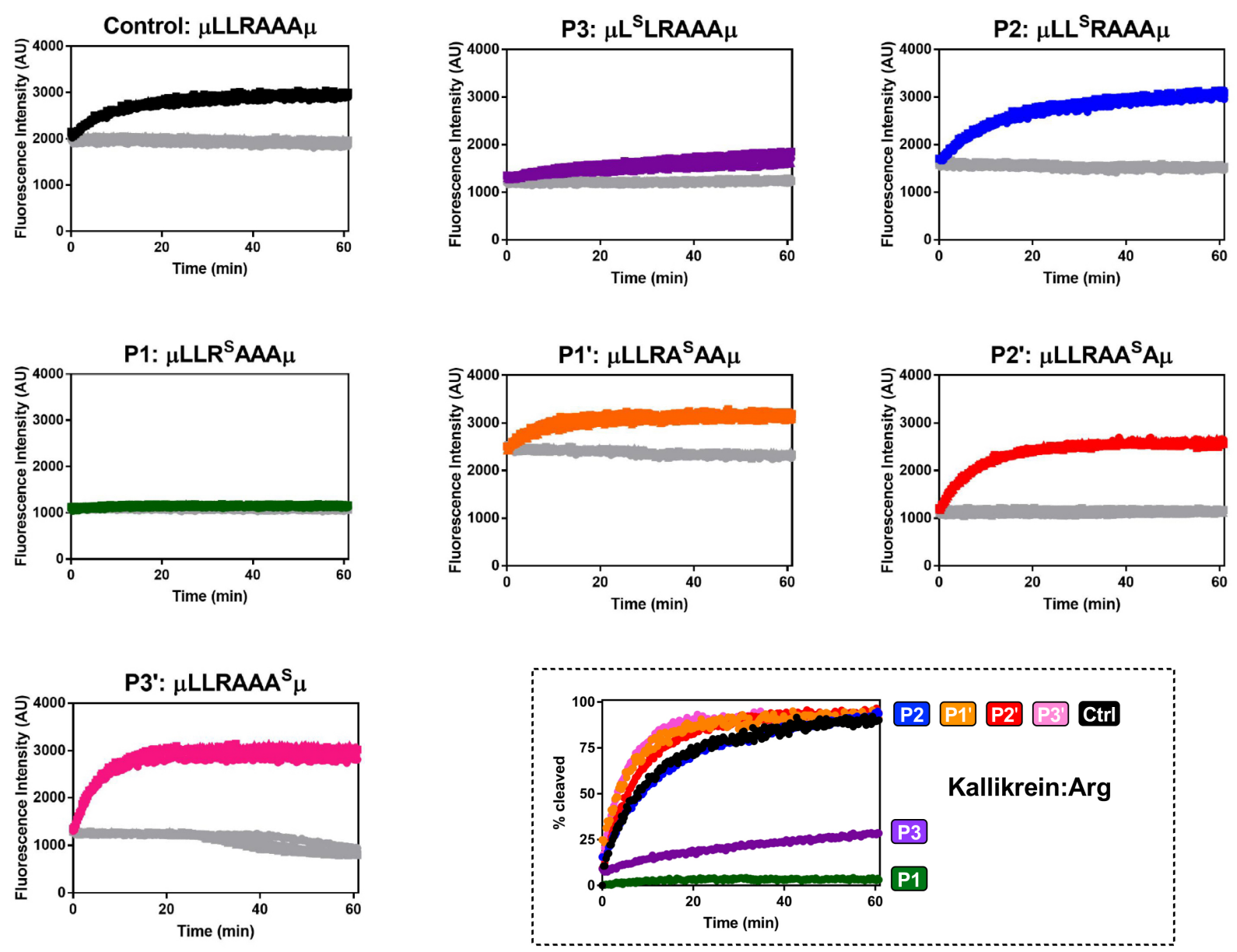

Figure S4. Kallikrein Proteolysis of Arg Peptides Monitored by Fluorescence. A 7.5 $\mu$ M solution of peptide was incubated in the presence or absence of $4.26 \mu \mathrm{g} / \mathrm{mL}$ kallikrein in $20 \mathrm{mM}$ Tris- $\mathrm{HCl}, 100 \mathrm{mM} \mathrm{NaCl}, \mathrm{pH}$ 7.5 buffer at $25^{\circ} \mathrm{C}$. Three independent trials for each peptide are shown. Black trace: All amide Arg Control peptide in the presence of protease; Colored traces: Arg thioamide peptides in the presence of protease; Grey traces: Thioamide peptides or control peptide in the absence of protease. Inset: Normalized cleavage data for control and thioamide peptides colored as indicated. 


\section{Kinetic Analysis of P1 Thioamide Peptides}

Kinetic Assays at Varying Substrate Concentrations. Various concentration of the Lys or Arg Control peptides were treated with $0.1 \mu \mathrm{M}$ of trypsin in $67 \mathrm{mM}$ sodium phosphate buffer, $\mathrm{pH}$ 7.6, at $25{ }^{\circ} \mathrm{C}$ in a $96-w e l l$ plate. Various concentrations of the $\mathrm{P} 1$ thiopeptides were treated with 10 $\mu \mathrm{M}$ of trypsin in $67 \mathrm{mM}$ sodium phosphate buffer, $\mathrm{pH} 7.6$, at $25^{\circ} \mathrm{C}$ in a 96 -well plate. The fluorescence of the reaction was monitored as a function of time at $390 \mathrm{~nm}$ with an excitation wavelength of $325 \mathrm{~nm}$ on the Tecan plate reader. Three independent trials were performed for each assay to ensure reproducibility. Data were analyzed by subtracting an average of the fluorescence of the no protease control $\left(\mathrm{F}_{\mathrm{Min}}\right)$ from the average fluorescence of the plus protease wells at time $\mathrm{t}, \mathrm{F}(\mathrm{t})$. Then, fluorescence was converted to concentration of product (in $\mu \mathrm{M}$ ) using Eq. S1, where $F_{\text {Max }}$ is the average fluorescence of the plus protease wells over the final $1000 \mathrm{~s}$ of the assay, and $[\mathrm{S}]_{0}$ is the initial concentration of substrate.

$$
[\text { Product }]=[\mathrm{S}]_{0} \times \frac{\left(\mathrm{F}(\mathrm{t})-\mathrm{F}_{\text {Min }}\right)}{\left(\mathrm{F}_{\text {Max }}-\mathrm{F}_{\text {Min }}\right)}
$$

Kinetic Parameter Estimation in COPASI. Since limitations in the solubility of substrates and the low activity of trypsin toward the thioamide substrates precluded using a Michaelis-Menten model, the data were numerically fit using COPASI software to a reversible mass action model (Eq. S2) to determine $k_{1}$ and $k_{-1}$, and $k_{\text {cat }} .{ }^{4}$ In order to fit the data, progress curves were imported into COPASI, and the Parameter Estimation task was used. Initial concentrations of enzyme (E) and substrate $(\mathrm{S})$ were specified as those used in the experiment, while concentrations of the ES complex and product $(\mathrm{P})$ were set to zero. Initial parameter estimations were done using evolutionary programming with 200 generations and a population size of 20 . The starting values 
for $k_{1}, k_{-1}$, and $k_{\text {cat }}$ were set to 0.1 with upper and lower bounds set to $1 \times 10^{ \pm 100}$. Once the values converged and had a small standard deviation, the parameter estimation was run again with 1000 generations and a population size of 100 to confirm the robustness of these values. The goodness of fit can be observed in the relatively small standard deviations in the fitted parameters (Table S5) and by inspection of Figs. S5-S6.

$$
\mathrm{E}+\mathrm{S} \underset{k_{-1}}{\stackrel{k_{1}}{\longrightarrow}} \mathrm{ES} \stackrel{k_{2}}{\longrightarrow} \mathrm{E}+\mathrm{P}
$$

Table S5. Kinetic Parameters Estimated from Mass Action Analysis

\begin{tabular}{|c|c|c|c|}
\hline Substrate & $k_{1}\left(\mu \mathrm{M}^{-1} \bullet \min ^{-1}\right)$ & $k_{-1}\left(\min ^{-1}\right)$ & $k_{2}\left(\min ^{-1}\right)$ \\
\hline$\mu$ LLKAAA $\mu$ & $1.026 \pm 0.007$ & $<2.8 \times 10^{-6}$ & $106.2 \pm 0.9$ \\
\hline$\mu \mathrm{LLK}^{\mathrm{S}} \mathrm{AAA} \mu$ & $0.408 \pm 0.007$ & $46.56 \pm 0.82$ & $1.308 \pm 0.014$ \\
\hline$\mu$ LLRAAA $\mu$ & $5.724 \pm 0.114$ & $<8.4 \times 10^{-5}$ & $273.6 \pm 3.1$ \\
\hline$\mu \operatorname{LLR}^{\mathrm{S}} \mathrm{AAA} \mu$ & $0.438 \pm 0.156$ & $2.880 \pm 0.960$ & $0.126 \pm 0.002$ \\
\hline
\end{tabular}



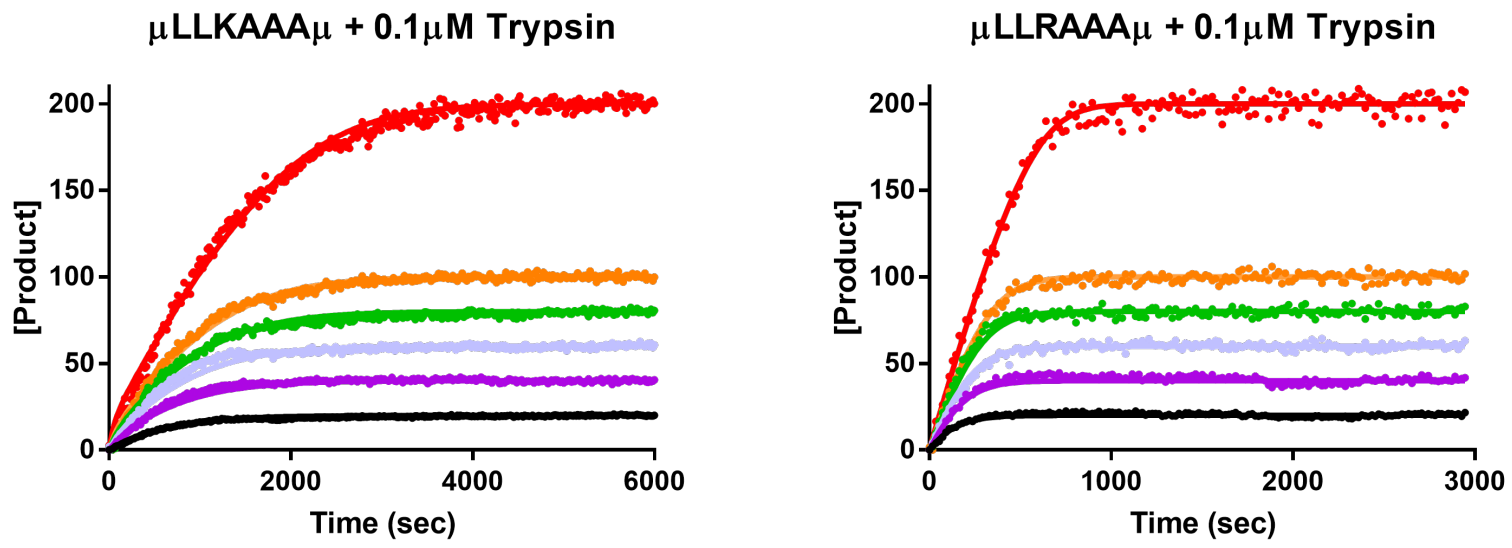

Figure S5. Kinetic Data Fitting for Control Peptides. Progress curves with COPASI fits of $\mu L L K A A A \mu$ (left) and $\mu$ LLRAAA $\mu$ (right) treated with trypsin. Various concentrations of peptide were incubated in the presence of $0.10 \mu \mathrm{M}$ trypsin in $67 \mathrm{mM}$ sodium phosphate buffer $(\mathrm{pH} 7.6)$ at $25^{\circ} \mathrm{C}$. [peptide]: $20 \mu \mathrm{M}, 40 \mu \mathrm{M}$, $60 \mu \mathrm{M}, 80 \mu \mathrm{M}, 100 \mu \mathrm{M}, 200 \mu \mathrm{M}$ in black, purple, lavender, green, orange, and red traces, respectively.

$\mu \operatorname{LLK}^{\mathrm{S}} \mathrm{AAA} \mu+10 \mu \mathrm{M}$ Trypsin

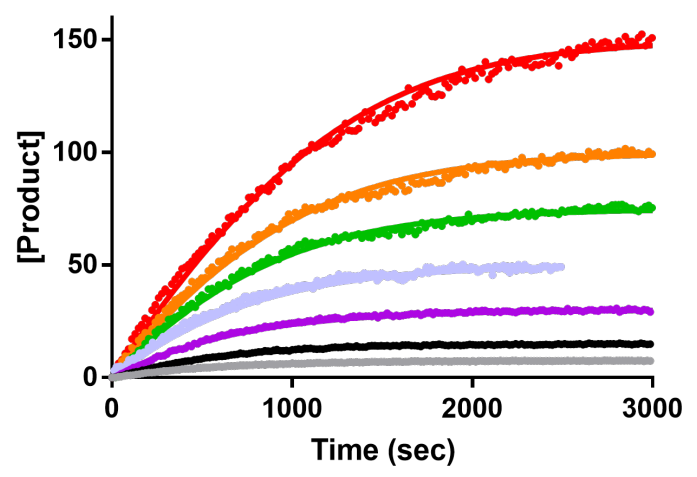

$\mu \operatorname{LLR}^{\mathrm{S}} \mathrm{AAA} \mu+10 \mu \mathrm{M}$ Trypsin

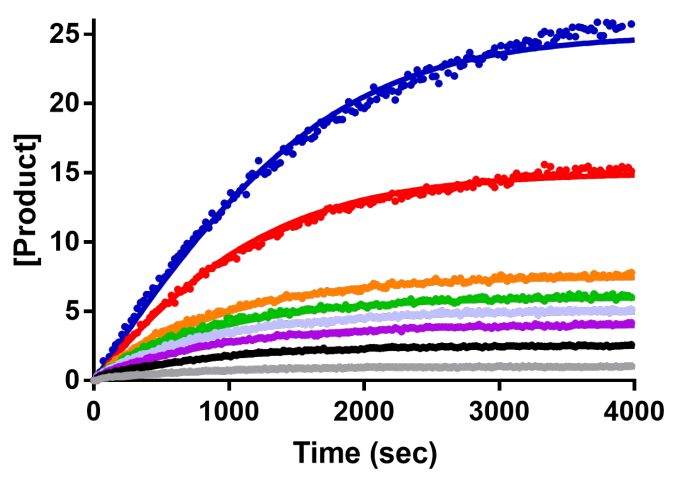

Figure S6. Kinetic Data Fitting for P1 Thioamide Peptides. Progress curves with COPASI fits of $\mu L L K^{\mathrm{S}} \mathrm{AAA} \mu$ (left) and $\mu \mathrm{LLR}^{\mathrm{S}} \mathrm{AAA} \mu$ (right) treated with trypsin. Various concentrations of peptide were incubated in the presence of $10 \mu \mathrm{M}$ trypsin in $67 \mathrm{mM}$ sodium phosphate buffer $(\mathrm{pH} 7.6)$ at $25{ }^{\circ} \mathrm{C}$. [ $\mu L L K^{\mathrm{S}} \mathrm{AAA} \mu \mathrm{]}$ : $7.5,15,30,50,75,100$, and $150 \mu \mathrm{M}$ in gray, black, purple, lavender, green, orange, and red traces, respectively. [ $\left.\mu L_{L} R^{S} A A A \mu\right]: 1.0,2.5,4.0,5.0,6.0,7.5,15$, and $25 \mu \mathrm{M}$ in gray, black, purple, lavender, green, orange, red, and blue traces, respectively. 
Inhibition Assay. Various concentrations of trypsin substrate $N$-benzoyl-L-arginine- $p$ nitroanilide (BAPNA) $(50 \mu \mathrm{M}, 100 \mu \mathrm{M}, 500 \mu \mathrm{M}, 1 \mathrm{mM}, 1.5 \mathrm{mM}, 2.0 \mathrm{mM}$, and $3.0 \mathrm{mM})$ were reacted with $25 \mu \mathrm{g} / \mathrm{mL}$ trypsin in $67 \mathrm{mM}$ sodium phosphate buffer, $\mathrm{pH} 7.6$, at $25^{\circ} \mathrm{C}$ in a $96-$ well plate. For thioamide inhibition, $100 \mu \mathrm{M}$ of Lys P1 or $80 \mu \mathrm{M}$ Arg P1was incubated with $25 \mu \mathrm{g} / \mathrm{mL}$ trypsin for $15 \mathrm{~min}$ at $25^{\circ} \mathrm{C}$ to allow for full interactions before adding the BAPNA substrates. The reaction was monitored by $\mathrm{UV}-\mathrm{V}$ is absorbance at $410 \mathrm{~nm}$ by the plate reader. Three trials were performed to ensure reproducibility. From the extinction coefficient of $p$-nitroaniline $\left(8800 \mathrm{M}^{-}\right.$ $\left.{ }^{1} \cdot \mathrm{cm}^{-1}\right)$, the absorbance was converted into the product $p$-nitroaniline concentration. The reaction rate was calculated by extracting the slope of a linear fit of the first $2 \mathrm{~min}$ of the cleavage reaction. The average of reaction rates from three trials were calculated used to construct a MichaelisMenten plot (Fig. S7). These curves were fit to Eq. $\mathbf{S 3}$ in Prism to determine $V_{\mathrm{Max}}$ and $K_{\mathrm{M}}$. Turnover number $\left(k_{\text {cat }}\right)$ was calculated by dividing $V_{\text {Max }}$ by the enzyme concentration.

$$
v_{0}=V_{\operatorname{Max}} \frac{[S]}{[S]+/ K_{M}}
$$

Table S6. Kinetic Parameters for Trypsin Inhibition by Thioamide Peptides.

\begin{tabular}{cccc}
\hline Condition & $\boldsymbol{k}_{\text {cat }}\left(\mathbf{s e c}^{-1}\right)$ & $\boldsymbol{K}_{\mathbf{M}}(\mathbf{m M})$ & $\boldsymbol{k}_{\text {cat }} / \boldsymbol{K}_{\mathbf{M}}\left(\mathbf{m M}^{-\mathbf{1}} \cdot \mathbf{s e c}^{-\mathbf{1}}\right)$ \\
\hline No Inhibitor & $0.049 \pm 0.0028$ & $1.59 \pm 0.32$ & $0.031 \pm 0.004$ \\
$100 \mu \mathrm{M} \mu \mathrm{LLK}^{\mathrm{S}} \mathrm{AAA} \mu$ & $0.088 \pm 0.0023$ & $2.17 \pm 0.62$ & $0.041 \pm 0.007$ \\
$80 \mu \mathrm{M} \mu \mathrm{LLR}^{\mathrm{S}} \mathrm{AAA} \mu$ & $0.045 \pm 0.0077$ & $0.65 \pm 0.19$ & $0.069 \pm 0.014$
\end{tabular}


L-BAPNA + 25 $\mu \mathrm{g} / \mathrm{mL}$ Trypsin

(No thiopeptide)
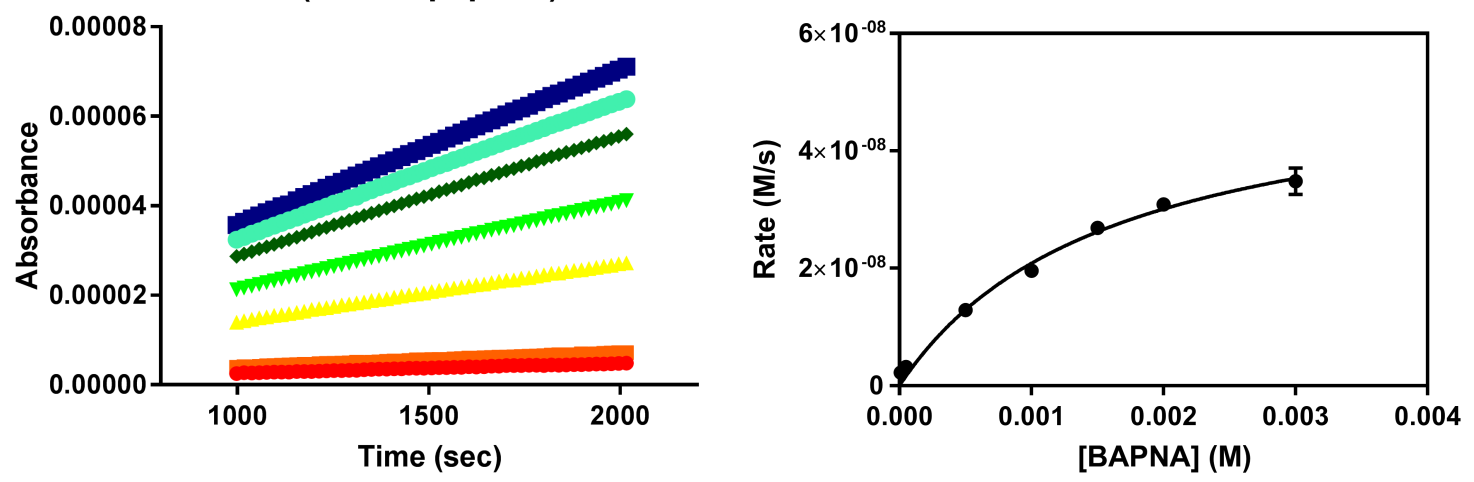

L-BAPNA $+25 \mu \mathrm{g} / \mathrm{mL}$ Trypsin $\left(80 \mu \mathrm{M} \mu \mathrm{LLR}^{\mathrm{S}} \mathrm{AAA} \mu\right)$
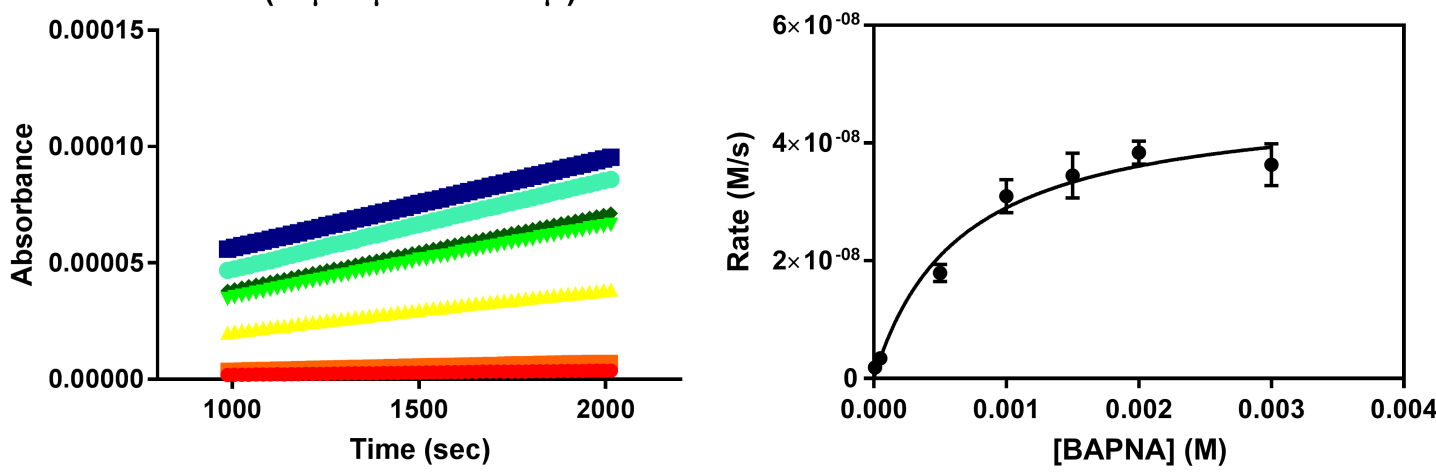

L-BAPNA $+25 \mu \mathrm{g} / \mathrm{mL}$ Trypsin $\left(100 \mu \mathrm{M} \mu\right.$ LLK $\left.^{\mathrm{S}} \mathrm{AAA} \mu\right)$
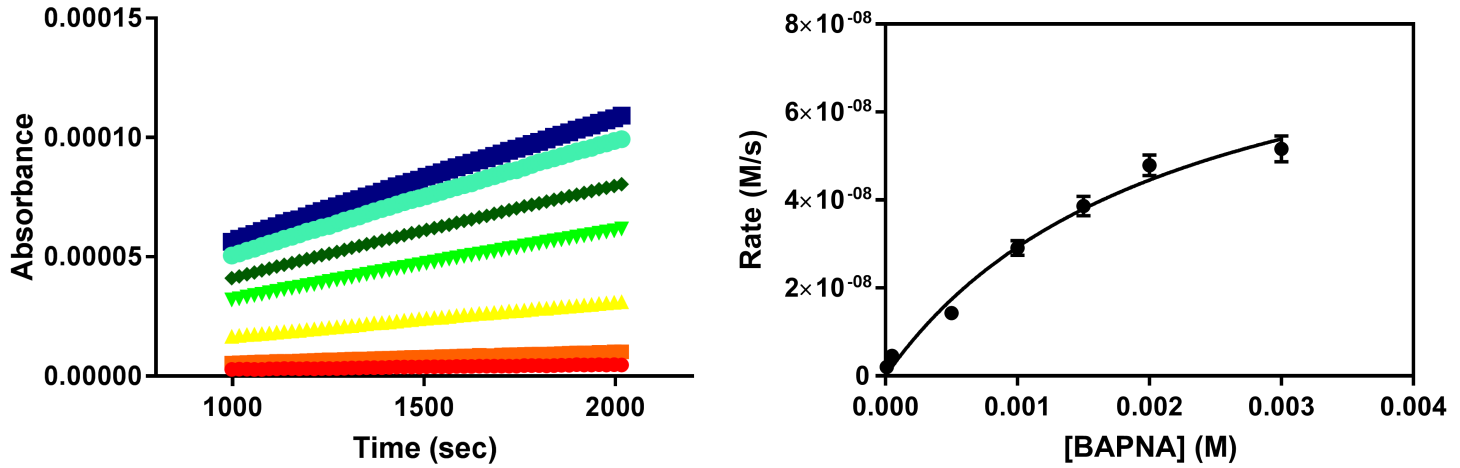

Figure S7. Trypsin Activity Monitored by Colorimetric Substrate BAPNA. Left: A $25 \mu \mathrm{g} / \mathrm{mL}$ trypsin solution was incubated in the presence or absence of thioamide peptides, then mixed with various concentrations of BAPNA. [BAPNA]: $50 \mu \mathrm{M}, 100 \mu \mathrm{M}, 500 \mu \mathrm{M}, 1 \mathrm{mM}, 1.5 \mathrm{mM}, 2 \mathrm{mM}$, and $3 \mathrm{mM}$ in red, orange, yellow, light green, dark green, teal, and dark blue, respectively. Right: Michaelis-Menten curves showing fits to Eq. S2. 


\section{Computational Modeling}

Structure Analysis: Modeling of LLKAAA Peptide Binding to Trypsin. The interaction between the $\mu$ LLKAAA $\mu$ "Oxo" peptide and trypsin was modeled using PyRosetta and the Rosetta Modeling Suite.-6 The PDB structure 2PTC was used as a starting structure of trypsin to simulate its docking interactions with the LLKAAA peptide. The native inhibitor peptide was trimmed both $\mathrm{N}$, and $\mathrm{C}$ terminally leaving only the VYGGCR 6-mer in the active site of trypsin. This peptide was converted to the LLKAAA peptide, using the mutate residue functionality within the PyRosetta toolbox. After generation of the target peptide in the active site of trypsin, the FlexPepDock refinement protocol within Rosetta was performed on the complex. The FlexPepDock protocol is a Monte-Carlo based simulation which applies gradient-based energy minimization to optimize the peptide's rigid body orientation relative to receptor protein it is docked with. During this optimization, both the peptide and enzyme sidechains and backbones are allowed to flexibly explore torsions. ${ }^{7}$ The refine FlexPepDocking protocol was run using the default parameters sampling 1000 decoys with constraints set with a weight of 100 Rosetta Energy Units (REUs). ${ }^{7}$ The 10 lowest energy structures, according to the FlexPep score, were visualized in PyMOL. ${ }^{7-8}$ As shown in Figure S8, all 10 output structures display nearly identical binding interactions spanning the entire peptide from positions P3 to P3'.

Following the FlexPepDock protocol, the lowest energy structure was subjected to two relax protocols. The Relax algorithm consists of sidechain repacking alongside gradient-based minimization of both backbone and side-chain torsion angles. Initially, the van der Waals repulsion score term is downweighed, but increases in weight with each applied cycle, ultimately returning to its default weight during the final cycle of the Relax..$^{9}$ A total of 100 trajectories were sampled, performing 10 FastRelax protocol executions per trajectory. ${ }^{9}$ Both protocols were performed using the "ref2015_cart" score function with the dualspace flag set to True. This flag corresponds to the optimization in latter stages of the protocol occurring in cartesian space. ${ }^{10}$ Minimizations were performed using the "lbfgs_armigo_nonmonotone" minimization method allowing for minimization of the bond angles. The difference between the two 
protocols was that the first included a Flat_Harmonic potential constraint of the active site serine oxygen to the P1 amide carbon with an energy of zero from 2 to $4 \AA$ with a standard deviation of $1 \AA$ dictating the harmonic profile outside of the zero-energy region). ${ }^{11}$ The lowest energy structure from the constrained relaxes was then put into an identical relax protocol without the constraint to ensure that the peptide was energetically stable in a cleavable orientation without being forced to be. The ten lowest energy structures observed during the final search were all practically identical in terms of peptide conformation $(<0.5 \AA$ RMSD across all peptide atoms). These are shown overlaid in Figure $\mathbf{S 9}$ and are shown separately in Figure S10. The energy in REU of each of the structures is plotted as a function of RMSD relative to the lowest energy structure in Figure S10. The peptide-enzyme hydrogen bonds observed in the "Relax" outputs were also observed in the FlexPepDock outputs, bolstering our confidence in these simulated docking interactions. The average hydrogen bond distances for all contacts made by the backbone amides in the 10 lowest energy structures are reported in Figure S10. The consensus structure from these simulations in shown in Figure 2 in the main text. 


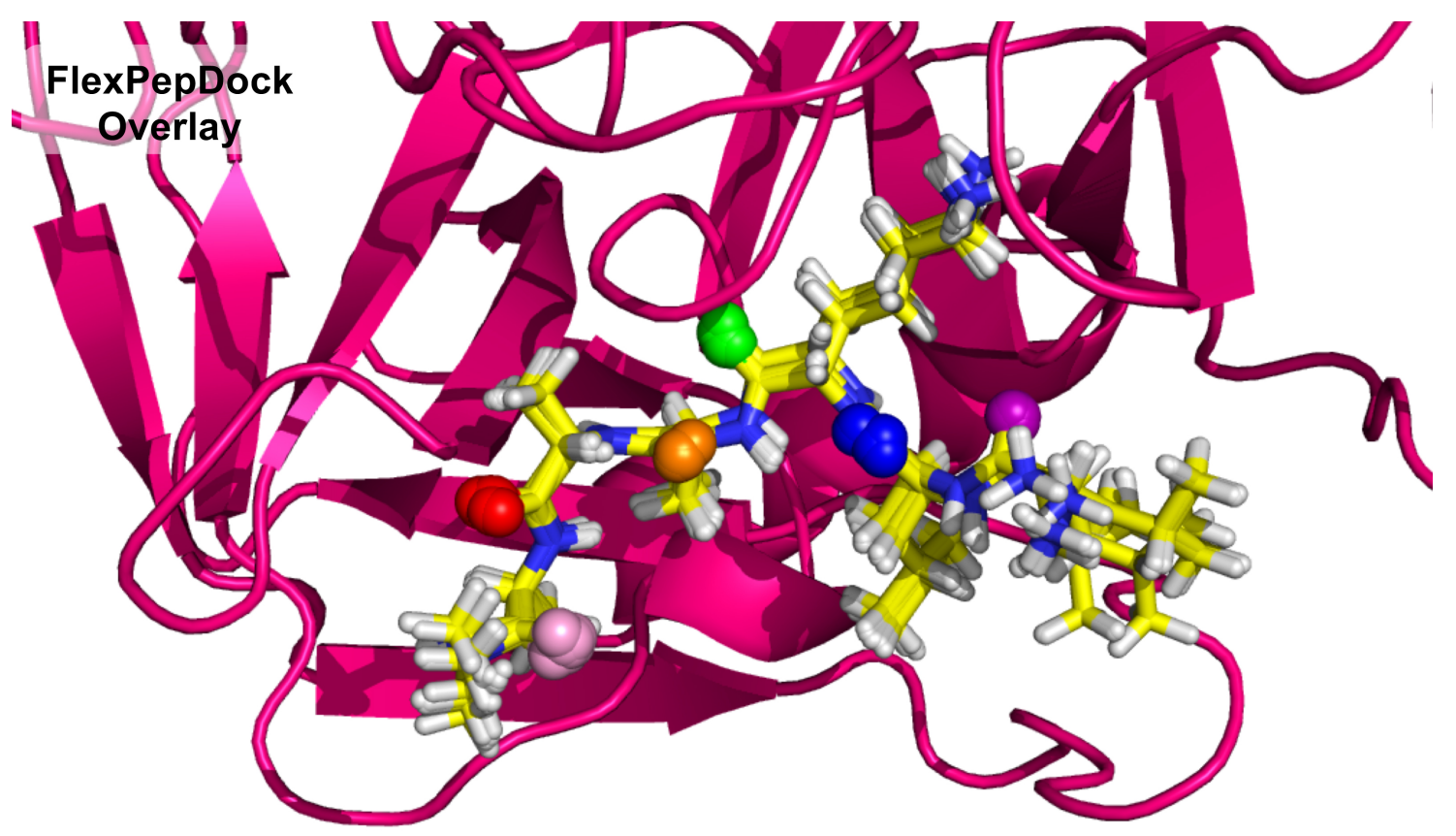

Figure S8. Overlay of Lowest Energy Structures from "FlexPepDock" Simulations of Trypsin. The 10 lowest energy structures of trypsin in complex with docked LLKAAA have minimal variations in carbonyl interactions of the P3 (purple), P2 (blue), P1 (green), P1' (orange), P2' (red), and P3' (pink) residues. Note: Protein backbone structure is static in these simulations.

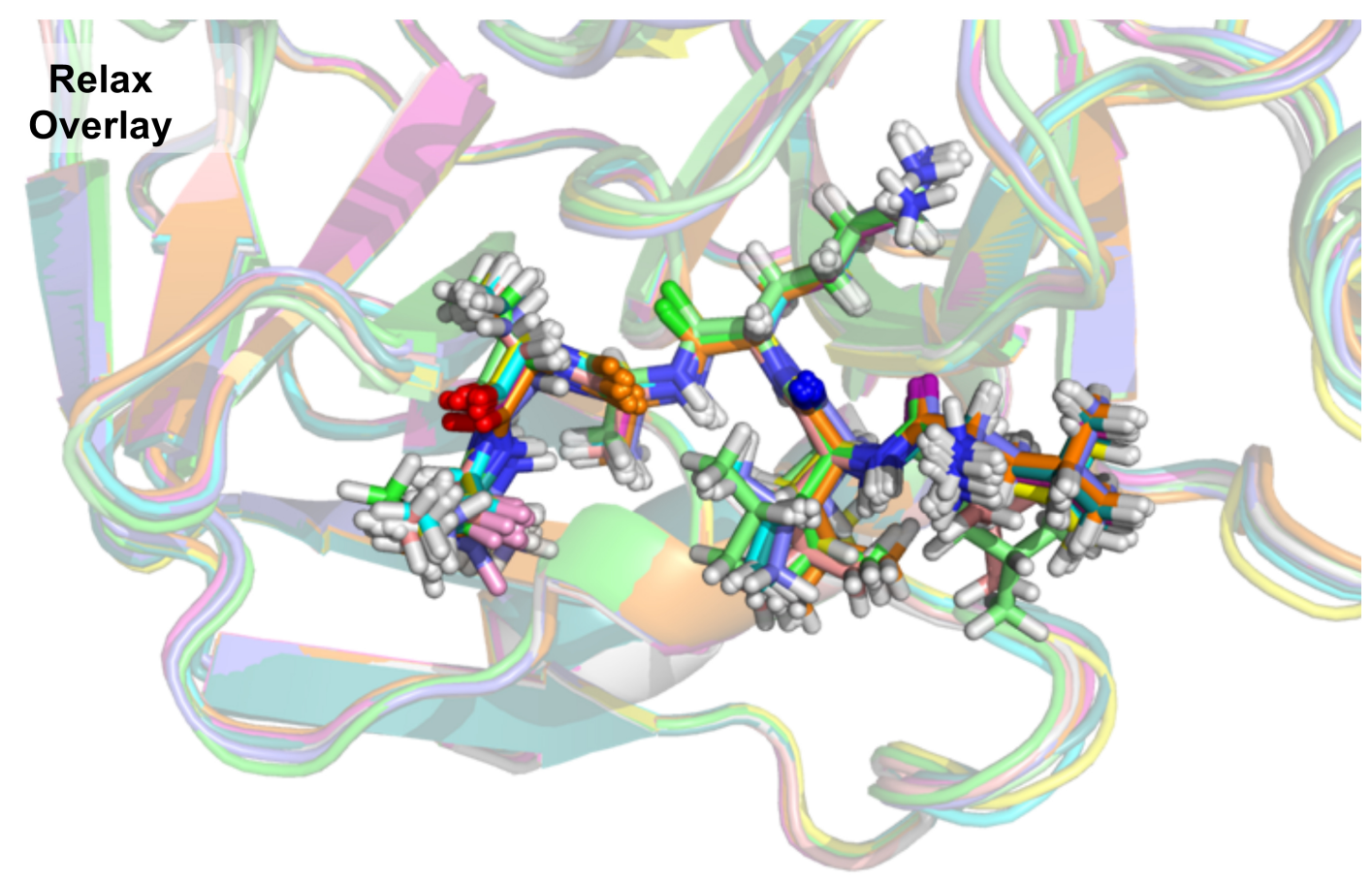

Figure S9. Overlay of Lowest Energy Structures from "Relax" Simulations of Trypsin. The 10 lowest energy structures of trypsin in complex with docked LLKAAA have minimal variations in carbonyl interactions of the P3 (purple), P2 (blue), P1 (green), P1' (orange), P2' (red), and P3' (pink) residues. In spite of extensive protein dynamics, the positions of the carbonyl atoms remain relatively fixed. 

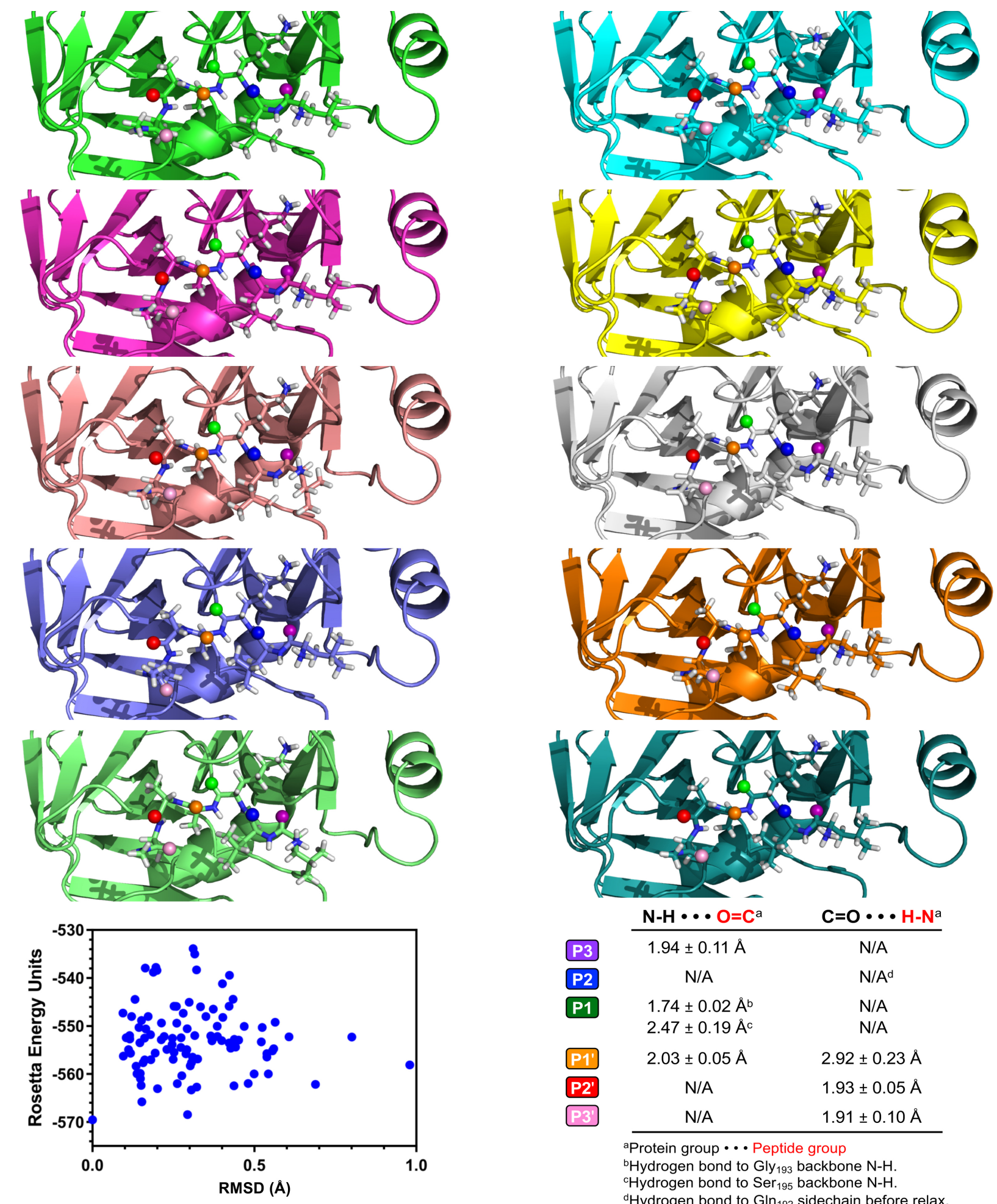

aProtein group $\cdots$ Peptide group

${ }^{b}$ Hydrogen bond to $\mathrm{Gly}_{193}$ backbone N-H.

cHydrogen bond to $\mathrm{Ser}_{195}$ backbone N-H.

dHydrogen bond to $\mathrm{Gln}_{192}$ sidechain before relax.

Figure S10. Lowest Energy Structures from "Relax" Simulations of Trypsin. Top: The 10 lowest energy structures of trypsin in complex with docked LLKAAA have minimal variations in carbonyl interactions of the P3 (purple), P2 (blue), P1 (green), P1' (orange), P2' (red), and P3' (pink) residues. Bottom Left: A plot of the energy (in Rosetta Energy Units, REU) as a function of the RMSD of each structure relative to the lowest energy structure from the Relax simulations. Bottom Right: Average O-to-H distances for amide hydrogen bonds from the 10 structures shown. 


\section{Imaging Peptide Studies}

Serum Stability Assay. A $25 \mu \mathrm{L}$ solution of $50 \mu \mathrm{M}$ TB1 or TB1-R ${ }_{6}$ in sterile Mill-Q water was incubated at $37^{\circ} \mathrm{C}$ in the presence of $25 \mu \mathrm{L}$ mouse serum (Sigma Aldrich M5905). After incubating for the desired time, the serum proteins were precipitated by adding $50 \mu \mathrm{L}$ methanol, and chilled at $-20{ }^{\circ} \mathrm{C}$ for $10 \mathrm{~min}$. After precipitation, samples were pelleted using an Eppendorf $5415 \mathrm{R}$ centrifuge at $13,000 \mathrm{RPM}$ for $10 \mathrm{~min}$ at $4{ }^{\circ} \mathrm{C}$. Next, $80 \mu \mathrm{L}$ of supernatant was diluted to $200 \mu \mathrm{L}$ with Milli-Q water and analyzed by HPLC, after the addition of $0.8 \mu \mathrm{L}$ of a $1.2 \mathrm{mM} 5,6-$ carboxyfluorescein internal standard solution. A Phenomenex Luna C8(2) analytical column (Torrance, CA, USA) was used to analyze all samples using the gradients shown in Table S7. MALDI MS was used to check peptide identities (Table S8). The amount of intact peptide was quantified based on peak areas in HPLC chromatograms (Fig. S11). All peptides were monitored at $484 \mathrm{~nm}$. The internal standard was used to normalize the amount of intact peptide in each sample. For each time point, samples were run in triplicate, and the amount of intact peptide was determined to be the average from three separate runs. To determine percent intact peptide, the average ratio of intact peptide to internal standard was compared to the ratio at $t=0$ for all samples. Percent intact peptide over two time points is shown in Figure S11 for TB1 peptides.

Table S7. HPLC Gradient for Serum Stability Assay*.

\begin{tabular}{cc}
\hline Time (min) & \%B \\
\hline $0: 00$ & 2.0 \\
$5: 00$ & 2.0 \\
$15: 00$ & 30.0 \\
$35: 00$ & 50.0 \\
$37: 00$ & 100.0 \\
$39: 00$ & 100.0 \\
$41: 00$ & 2.0 \\
\hline
\end{tabular}

*Solvent A: $0.1 \%$ TFA in water; Solvent B: $0.1 \%$ TFA in acetonitrile 
Table S8. Retention Times and Masses of TB1 Peptides.

\begin{tabular}{ccc}
\hline Peptide & Retention Time (min) & Observed Mass $(\mathbf{m} / \mathbf{z})$ \\
\hline TB1 & 26.2 & 1795.00 \\
${\text { TB } 1-\mathrm{R}^{\mathrm{S}}}_{6}$ & 27.5 & 1810.75
\end{tabular}
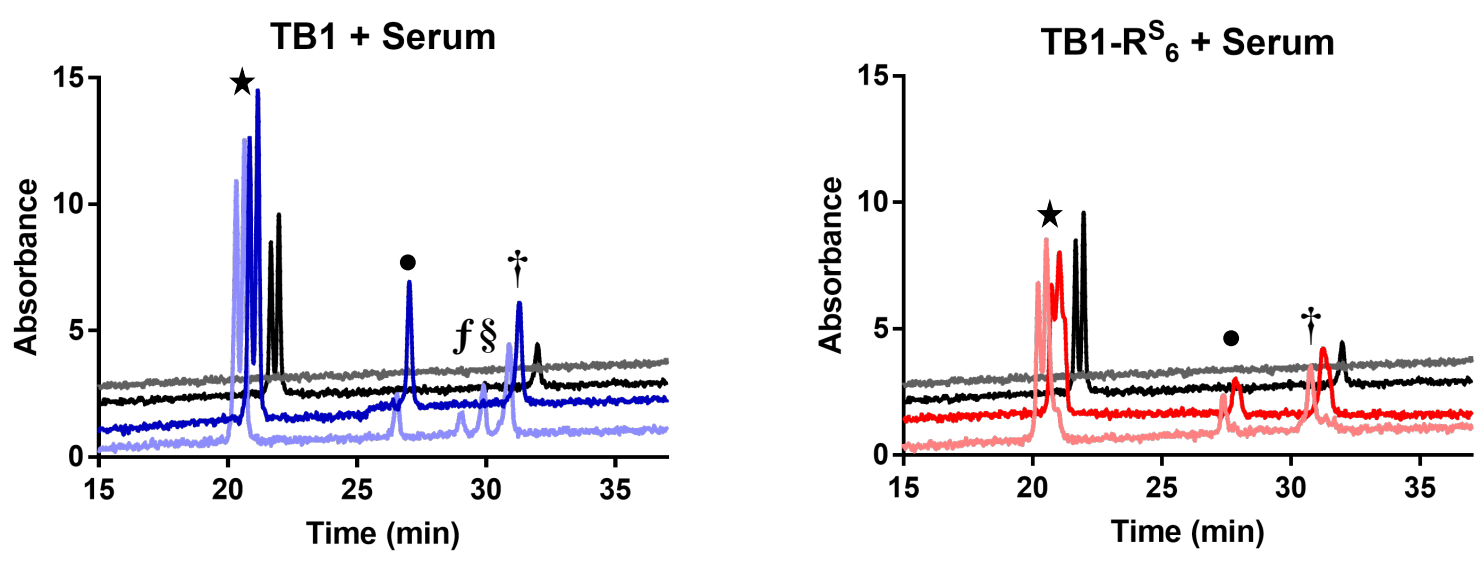

Figure S11. Serum Stability Assay. Representative HPLC chromatograms. Absorbance was monitored at $484 \mathrm{~nm}$. Left: Dark blue curve is at zero min, light blue curve is at $90 \mathrm{~min}$, black curve is internal standard alone, and gray curve is serum alone; * indicates 5,6-carboxyfluorescein internal standard, $\bullet$ indicates intact peptide (observed mass: $1795.9 \mathrm{~m} / \mathrm{z}$ ), $\S$ indicates cleavage of TB1 $1_{1-5}$ (observed mass: $1477.4 \mathrm{~m} / \mathrm{z}$, theoretical mass: $1475.7 \mathrm{~m} / \mathrm{z}$ ), and $\dagger$ indicates internal standard bound to serum proteins (other cleavage product indicated $f$ by could not be identified by MALDI MS). Right: Dark red curve is at zero $\mathrm{h}$, light red curve is at $8 \mathrm{~h}$, black curve is internal standard (5,6-carboxyfluorescein) alone, and gray curve is serum alone; * indicates 5,6-carboxyfluorescein internal standard, - indicates intact peptide (observed mass: $1810.6 \mathrm{~m} / \mathrm{z}$ ), and † indicates internal standard bound to serum proteins. 
Neuropeptide Y Y1R Activation Assay. To determine the $K_{\mathrm{i}}$ of TB1 and TB1-R ${ }_{6}^{\mathrm{S}}$, a DiscoverX PathHunter ${ }^{\circledR}$ eXpress NPY1R CHO-K1 $\beta$-Arrestin GPCR Assay was employed. Provided cells were thawed and plated onto a 96 well plate and stored in a $37{ }^{\circ} \mathrm{C}$ incubator with $5 \% \mathrm{CO}_{2}$ for 48 h. Solutions of both peptides in DPBS buffer at varying concentrations were plated into a separate 96 well plate to be transferred to the assay plate. Cells were treated with $5 \mu \mathrm{L}$ of TB1 or TB1-R ${ }_{6}$ antagonist for $30 \mathrm{~min}$ in the incubator $\left(37^{\circ} \mathrm{C}\right.$ with $\left.5 \% \mathrm{CO}_{2}\right)$, followed by treatment with $5 \mu \mathrm{L}$ of $50 \mathrm{nM}$ (final working concentration) peptide $\mathrm{YY}(\mathrm{PYY})$ for $1.5 \mathrm{~h}$ in in the incubator $\left(37^{\circ} \mathrm{C}\right.$ with $\left.5 \% \mathrm{CO}_{2}\right)$. Next, cells were treated with the detection solution provided in the assay kit and allowed to incubate at room temperature for $1 \mathrm{~h}$. Finally, the assay plate luminescence was read on a Tecan M1000pro in luminescence mode (no filter) with an integration time of $100 \mathrm{~ms}$ after incubation at $1 \mathrm{~h}$ and $3 \mathrm{~h}$ post-treatment. Within each trial, luminescence signal was normalized to the maximum (treatment with $50 \mathrm{nM} \mathrm{PYY)} \mathrm{and} \mathrm{the} \mathrm{minimum} \mathrm{(treatment} \mathrm{with} \mathrm{buffer).} \mathrm{The} \mathrm{normalized} \mathrm{data} \mathrm{were}$ then analyzed by averaging data across three independent biological replicates (different batches of cells) on different days. A few data sets or data points were dropped because outlier data points at the high or low concentrations made it infeasible to normalize the data in a sensible way. The final data set consisted of 7-8 data points at each concentration for both TB1 and TB1- $\mathrm{R}^{\mathrm{S}}$, with at least two trials in every biological replicate. These averaged plots are shown in Figure $\mathbf{4}$ in the main text. These averaged data were fit to Eq. $\mathbf{S 4}$ in Kaleidagraph (to determine an $\mathrm{IC}_{50}$ for competition with PYY.

$$
\text { Norm. Luminescence }=1-\frac{[\mathrm{L}]}{[\mathrm{L}]+\mathrm{IC}_{50}}
$$

The $\mathrm{IC}_{50}$ values determined for $\mathrm{TB} 1$ and $\mathrm{TB} 1-\mathrm{R}_{6}^{\mathrm{S}}(719 \pm 143 \mathrm{nM}$ and $1363 \pm 323 \mathrm{nM}$, respectively) were then used to calculate $K_{\mathrm{I}}$ values using Eq. S5, where [L] is $50 \mathrm{nM}$ PYY and the 
$\mathrm{EC}_{50}$ for PYY is $4.1 \mathrm{nM}$, according to the assay manufacturer, DiscoverX (https://www.discoverx.com/getmedia/782b3f48-40b1-45ae-a6c2-f6827c9d8f5f/93-0397E2CP0M.aspx).

$$
K_{\mathrm{I}}=\frac{\mathrm{IC}_{50}}{1+[\mathrm{L}] / \mathrm{EC}_{50}}
$$

$K_{\mathrm{I}}$ values of $53.0 \pm 10.6 \mathrm{nM}$ and $101 \pm 23.9 \mathrm{nM}$ were determined for $\mathrm{TB} 1$ and $\mathrm{TB} 1-\mathrm{R}^{\mathrm{S}}$, respectively, with error propagated according to NIST Handbook guidelines (https://www.itl.nist.gov/div898/handbook/mpc/section5/mpc552.htm).
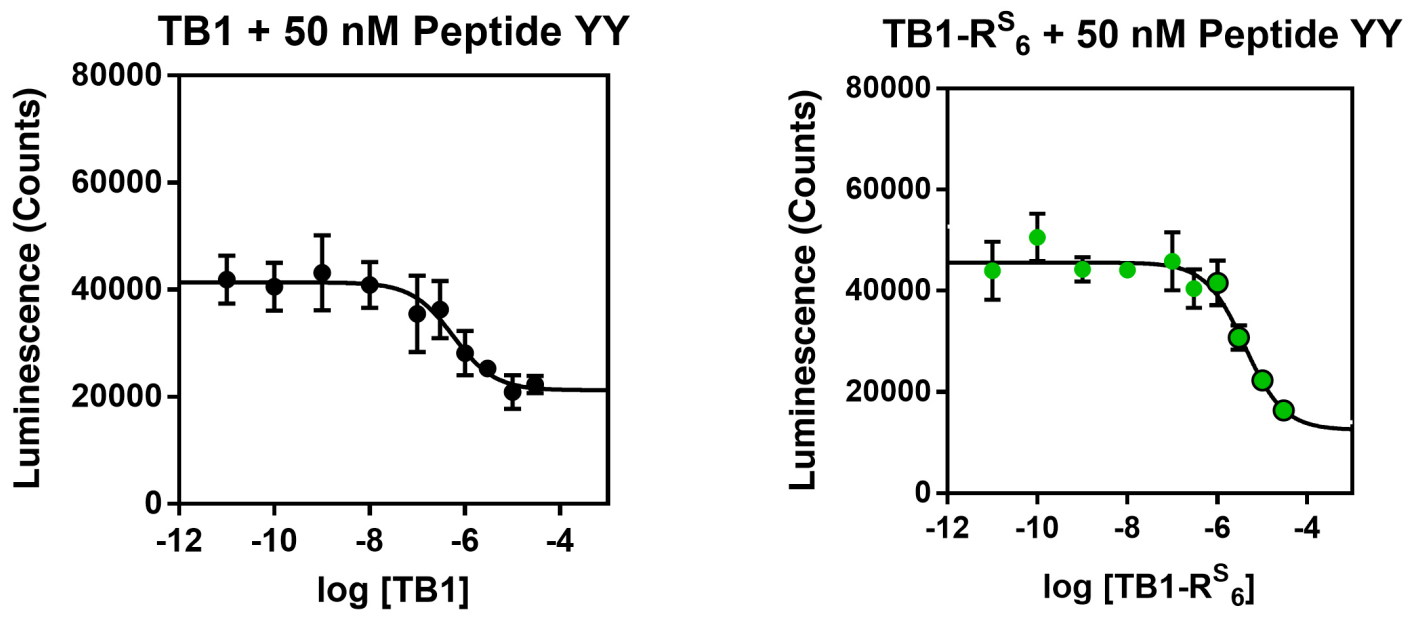

Figure S12. Representative TB1 and TB1- $\mathrm{R}_{6}$ Binding Trials. Luminescence signal after treatment of cells with $50 \mathrm{nM}$ peptide $\mathrm{YY}$ followed by various concentrations of TB1 or TB1- $\mathrm{R}_{6}$. Traces shown are averages of three technical replicates from one biological replicate of the DiscoverX PathHunter $\AA$ eXpress NPY1R $\mathrm{CHO}-\mathrm{K} 1 \beta$-Arrestin GPCR Assay. Open symbols indicate that only two trials were included in final set of 7-8 data sets across all three biological replicates. Black curve: TB1, Green curve: TB1-RS ${ }_{6}$. 
Cell Culture and Imaging. The following media were used in cell culture: DMEM (Corning), 10\% FBS (Atlanta Biologicals), 1\% Glutamine Supplement (Gibco), 1\% Penicillin/Streptomycin (Gibco). MCF-7 and QBI-293 cultures were synchronized prior to experiments. For cellular imaging, cells were plated onto $35 \mathrm{~mm}$ MatTek dishes, pre-treated with poly-D-lysine containing a $10 \mathrm{~mm}$ diameter glass insert 2 days prior to imaging at $37{ }^{\circ} \mathrm{C}$ in $5 \% \mathrm{CO}_{2}$. Immediately prior to the experiment, medium was removed by aspiration and wells were washed $1 \mathrm{X}$ with $1 \mathrm{~mL}$ Hanks Balanced Salt Solution (HBSS, Gibco). Treatments were performed on MCF-7 and QBI-293 cells in parallel. All studies were conducted at room temperature. For imaging of the peptide alone, $500 \mu \mathrm{L}$ of HBSS containing Hoechst 33342 was added to the plate, followed by $500 \mu \mathrm{L}$ of $500 \mathrm{nM}$ TB1 or TB1- $\mathrm{R}_{6}$ in HBSS for 15 min (final concentration of $250 \mathrm{nM}$ peptide). For competition binding studies, $1 \mu \mathrm{M}$ NPY in HBSS was added directly to the plate after HBSS wash and incubated for $30 \mathrm{~min}$ at room temperature before treatment using the conditions above. At the completion of each experiment, wells were washed $3 \mathrm{X}$ with HBSS and immediately imaged using a VT-iSIM confocal microscope (Hoechst excitation $=405 \mathrm{~nm}$; Fluorescein excitation $=488 \mathrm{~nm}$ ). Images were compiled using Image J (NIH). For each Z-stack, the first 10 stacks were combined into a composite image. All brightness, contrast, etc. settings for the images in the main text and in Figure S13 are normalized to the same values and smoothed. 

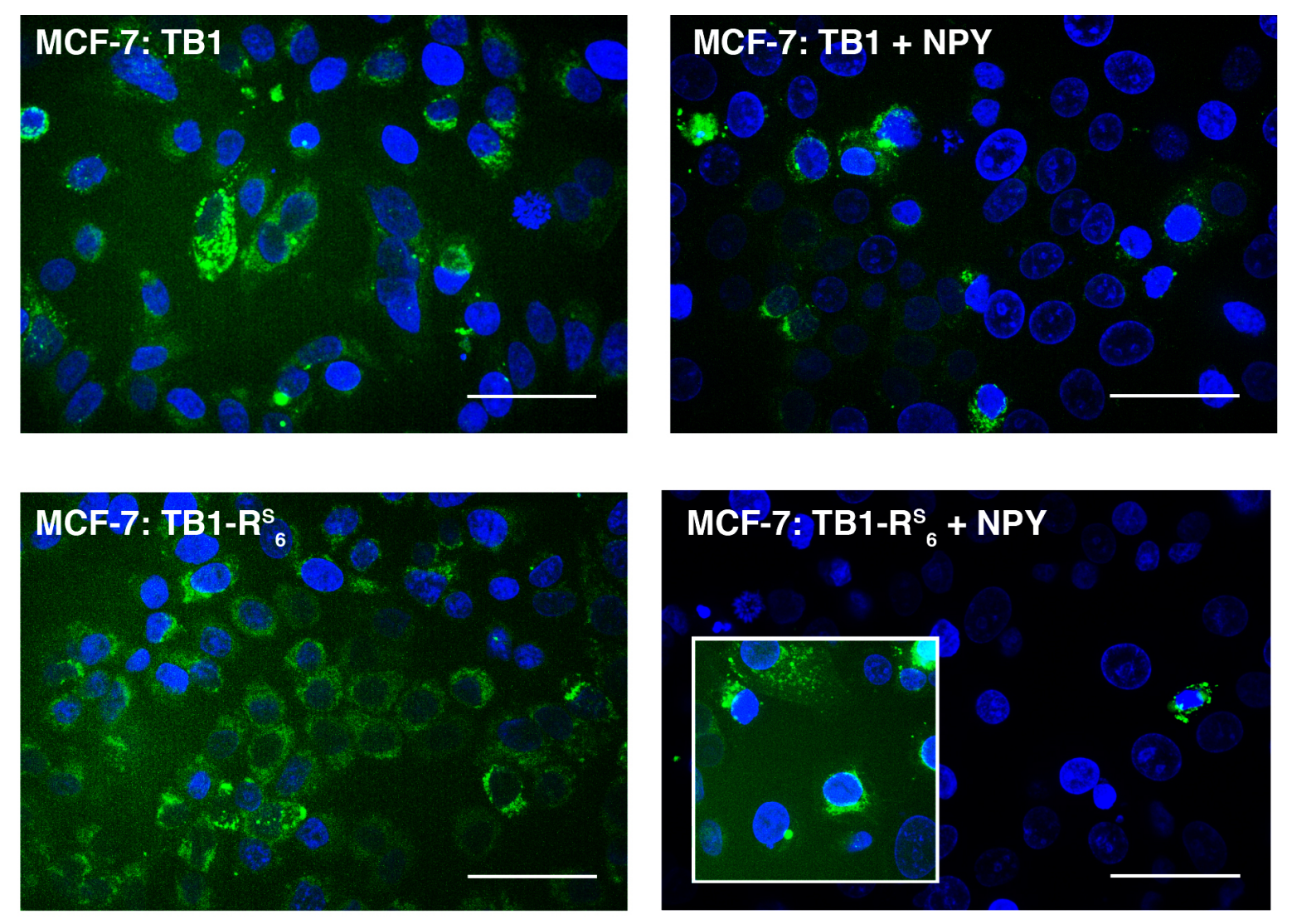

Figure S13. Additional Representative Images of TB1 and TB1- $\mathrm{R}_{6}$ Cell Binding. MCF-7 cells were incubated with $250 \mathrm{nM}$ TB1 or TB1-R ${ }_{6}$ for 15 min before imaging. For + NPY conditions, cells were preincubated with $1 \mu \mathrm{M}$ NPY. Inset: In some cases, signal from TB1 or TB1-R ${ }_{6}$ was observed in + NPY conditions, possibly due to insolubility or unblockable internalization. Scale bar indicates $50 \mu \mathrm{m}$.

Fluorescence Lifetime Analysis. TCSPC measurements of fluorescence lifetime decays were collected using a pulsed LED with a maximum emission at $486 \mathrm{~nm}$. Fluorescence was collected at $515 \mathrm{~nm}$ with the slit widths adjusted for each measurement to keep the ACD value between $1-3$ $\%$ of the SYNC value. The instrument response function (IRF) was collected for each slit width used for collection. For these experiments labeled TB1 or TB1- $\mathrm{R}_{6}{ }_{6}$ were diluted to $175 \mu \mathrm{M}$ in water. Lifetime data were fit using PowerFit10 distributed by PTI. Each decay was fit to a single exponential decay where the time regime was selected to minimize the chi-squared values and the residuals. 


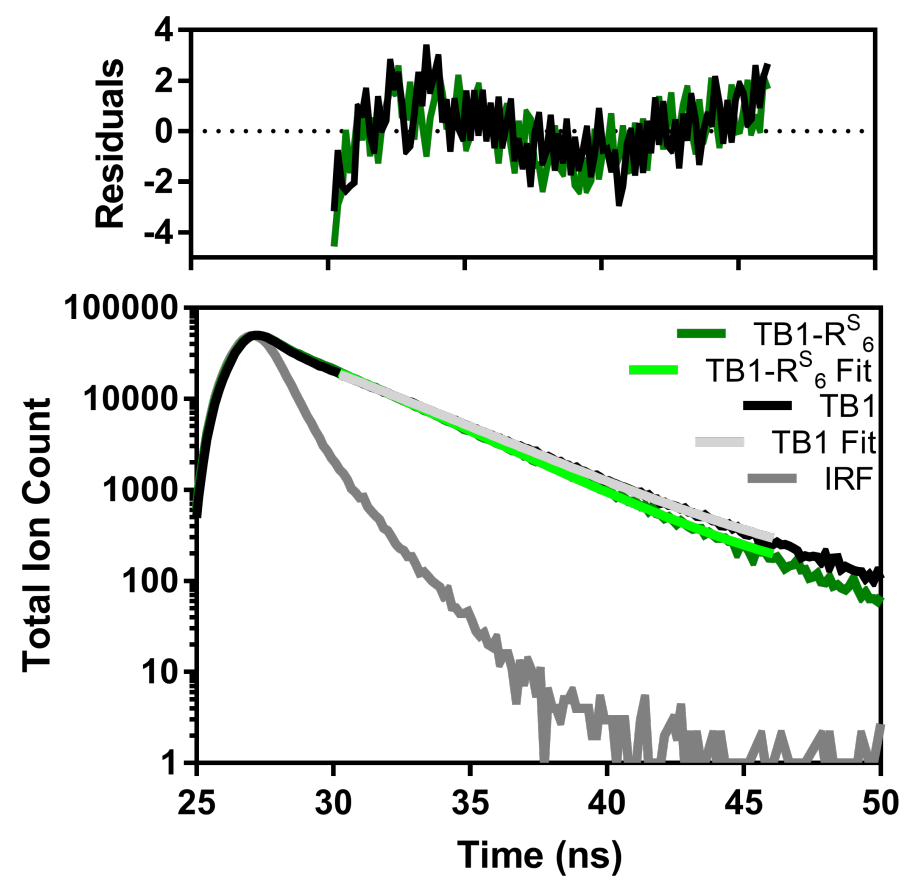

Figure S14. Fluorescence Lifetime Measurements of TB1 and TB1- ${ }^{S}{ }_{6}$ Peptides. TB1 (black) and TB1$\mathrm{R}_{6}{ }_{6}$ (green) fluorescence decays for $175 \mu \mathrm{M}$ solutions in water. The instrument response function (IRF) is shown in grey. IRF-corrected single exponential fits to the decay data provide lifetime values of $3.452 \pm$ 0.010 for TB1 and $3.076 \pm 0.007$ for TB1- ${ }^{S_{6}}$. 


\section{References}

1. Liu, C.; Barrett, T. M.; Chen, X.; Ferrie, J. J.; Petersson, E. J., Fluorescent Probes for Studying Thioamide Positional Effects on Proteolysis Reveal Insight into Resistance to Cysteine Proteases. ChemBioChem 2019, 20, 2059-2062.

2. Goldberg, J. M.; Chen, X.; Meinhardt, N.; Greenbaum, D. C.; Petersson, E. J., ThioamideBased Fluorescent Protease Sensors. J. Am. Chem. Soc. 2014, 136, 2086-2093.

3. Szantai-Kis, D.; Walters, C.; Barrett, T.; Hoang, E.; Petersson, E., Improved Fmoc Deprotection Methods for the Synthesis of Thioamide-Containing Peptides and Proteins. Synlett 2017, 28, 1789-1794.

4. Hoops, S.; Sahle, S.; Gauges, R.; Lee, C.; Pahle, J.; Simus, N.; Singhal, M.; Xu, L.; Mendes, P.; Kummer, U., Copasi-a Complex Pathway Simulator. Bioinformatics (Oxford, England) 2006, 22, 3067-3074.

5. Kaufmann, K. W.; Lemmon, G. H.; Deluca, S. L.; Sheehan, J. H.; Meiler, J., Practically Useful: What the Rosetta Protein Modeling Suite Can Do for You. Biochemistry 2010, 49, 2987-2998.

6. Chaudhury, S.; Lyskov, S.; Gray, J. J., Pyrosetta: A Script-Based Interface for Implementing Molecular Modeling Algorithms Using Rosetta. Bioinformatics (Oxford, England) 2010, 26, 689-691.

7. Raveh, B.; London, N.; Schueler-Furman, O., Sub-Angstrom Modeling of Complexes between Flexible Peptides and Globular Proteins. Proteins 2010, 78, 2029-2040.

8. Schrodinger, LLC The Pymol Molecular Graphics System, Version 1.8, 2015.

9. Conway, P.; Tyka, M. D.; DiMaio, F.; Konerding, D. E.; Baker, D., Relaxation of Backbone Bond Geometry Improves Protein Energy Landscape Modeling. Protein Sci. 2014, 23, 47-55.

10. Alford, R. F.; Leaver-Fay, A.; Jeliazkov, J. R.; O’Meara, M. J.; DiMaio, F. P.; Park, H.; Shapovalov, M. V.; Renfrew, P. D.; Mulligan, V. K.; Kappel, K.; Labonte, J. W.; Pacella, M. S.; Bonneau, R.; Bradley, P.; Dunbrack, R. L.; Das, R.; Baker, D.; Kuhlman, B.; Kortemme, T.; Gray, J. J., The Rosetta All-Atom Energy Function for Macromolecular Modeling and Design. J. Chem. Theory Comput 2017, 13, 3031-3048.

11. Cordara, G.; van Eerde, A.; Grahn, E. M.; Winter, H. C.; Goldstein, I. J.; Krengel, U., An Unusual Member of the Papain Superfamily: Mapping the Catalytic Cleft of the Marasmius Oreades Agglutinin (Moa) with a Caspase Inhibitor. PLOS ONE 2016, 11, e0149407. 